\section{Acta}

\section{J.Plendl \\ F. Sinowatz}

Institute for Veterinary Anatomy, University of Munich, Germany

\title{
Glycobiology of the Olfactory System
}

\section{Key Words}

Olfactory system

Vomeronasal system

Neuron

Glycoconjugate

Lectin

Cell adhesion

Extracellular matrix

Development
Abbreviations used in this paper:

$\mathrm{BSA}=$ Bovine serum albumine; BSA I=Bandeiraea simplicifolia agglutinin I;

Con $\mathrm{A}=$ concanavalin $\mathrm{A} ; \mathrm{DBA}=$ Dolichos biflorus agglutinin; $\mathrm{LH}-\mathrm{RH}=$ luteinizing

hormone-releasing hormone; mRNA = messenger RNA; N-CAM= neural cell adhesion molecule; NILE = nerve growth factor-inducible large external; NMRI=Naval Medical

Research Institute; PNA = peanut agglutinin; $\mathrm{SBA}=$ soybean agglutinin; UEA I=Ulex

europaeus agglutinin; VVA = Vicia villosa agglutinin; $\mathrm{WGA}=$ wheat germ agglutinin

\begin{abstract}
The olfactory system is a highly plastic region of the nervous system. Continuous remodeling of neuronal circuits in the olfactory bulb takes place throughout life as a result of constant turnover of primary sensory olfactory neurons in the periphery. Glycoconjugates are very important in olfactory development, regeneration and function. This article deals with different aspects of glycobiology relevant for the olfactory system. Various anatomical, developmental and functional subdivisions of the olfactory system have been labeled with exogenous lectins. The application of reverse lectin histochemistry resulted in the visualization of endogenous lectins, involved in fasciculation of olfactory axons. Numerous glycoproteins, among them members of the immunoglobulin superfamily, the cadherins and integrins as well as different glycolipids and proteoglycans can act as surface adhesion molecules in the olfactory system. The olfactory-specific form of the sialoglycoprotein neural cell adhesion molecule is implicated in olfactory neuronal and axonal guidance. Glycoconjugates including laminin, fibronectin and proteoglycans are abundant components of the olfactory extracellular matrix, influencing neurite outgrowth and cellular migration. Immunohistochemical labeling has revealed occurrence of the carbohydrate differentiation antigen, playing a role in neurulation and morphogenesis of the very early olfactory system. The synaptic vesicle glycoprotein, appearing also early in olfactory development, is used as a marker of olfactory tumors. Finally, membrane and transmembrane glycoconjugates as well as secreted glycoconjugates may act as olfactory receptor molecules.
\end{abstract}

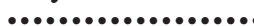

\section{Introduction}

The olfactory system is remarkable in its ability to recognize and discriminate numerous airborne molecules. In most vertebrates, chemical signals are perceived and transduced by two clearly distinct olfactory systems, the main and the accessory or vomeronasal system. The peripheral part of the olfactory system, the olfactory epithelium, is composed of basal cells, supporting cells and millions of olfactory receptor neurons. These latter cells are bipolar

\section{KARGER \\ Fax+4161306 1234 \\ E-Mail karger@karger.ch} www.karger.com
(C) 1998 S. Karger AG, Basel

0001-5180/98/1614-0234\$15.00/0

Accessible online at: http://BioMedNet.com/karger
Priv.-Doz. Dr. Johanna Plendl

Institute for Veterinary Anatomy

University of Munich

Veterinärstrasse 13, D-80539 München (Germany)

Tel. +49 892180 2566; Fax +49892180 2569 


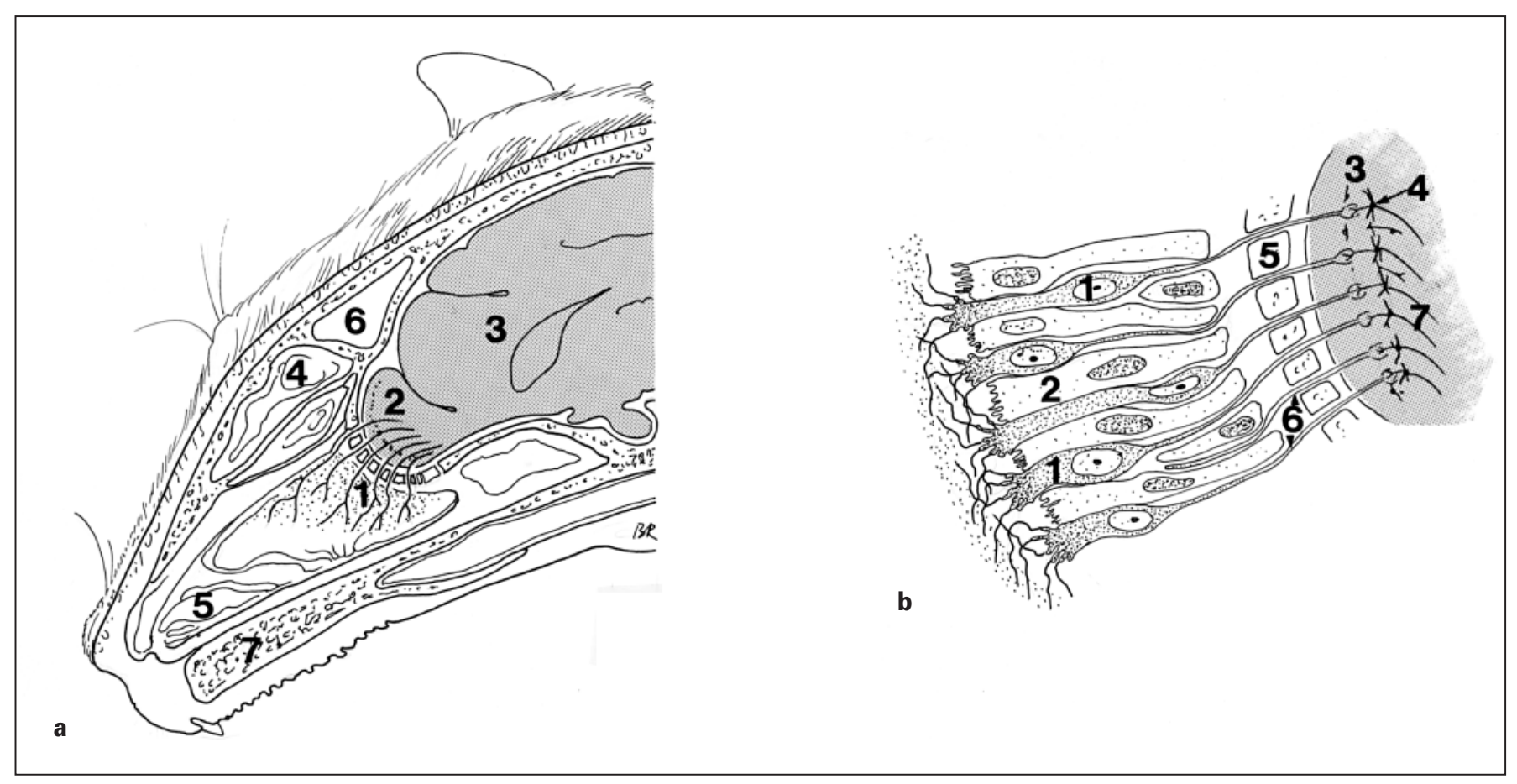

Fig. 1. a Anatomical scheme of the vertebrate olfactory system, parasagittal section. $1=$ Olfactory epithelium; $2=$ olfactory bulb; $3=$ cerebrum; $4=$ ethmoidal concha; $5=$ ventral nasal concha; $6=$ frontal sinus; $7=$ maxilla. b Diagram to demonstrate the connection between the olfactory receptor neurons and the olfactory bulb. $1=$ Olfactory receptor neuron; $2=$ supporting cells; $3=$ olfactory glomerulus (olfactory bulb); $4=$ mitral cells (olfactory bulb); $5=$ cribriform plate; $6=$ olfactory nerve; $7=$ olfactory tract.

neurons terminating in a multiciliated dendritic knob at the epithelial surface that protrudes into a mucus layer (fig. 1, 2). The olfactory axon arising from the proximal pole of the neuronal cell bodies fasciculates with other axons and passes through the lamina cribrosa into the olfactory bulb, where axonal fascicles branch and terminate in characteristic synaptic connections called olfactory glomeruli (fig. 1b). Axons from the main olfactory epithelium end in the main olfactory bulb, whereas those of the accessory olfactory system end in the accessory bulb (fig. 3) [Barber and Raisman, 1978; Graziadei and Monti Graziadei, 1979; Breipohl, 1986].

Olfactory receptor cells are very unusual neurons. They have a limited life span and are replaced by new neurons which migrate into the upper compartment of the epithelium following their formation from the stem cells in the basal portion. Also, if these neurons, which have direct contact with the external environment, are damaged or destroyed, neuronal regeneration occurs regularly and the olfactory epithelium is reconstituted. Thus, the only known structure of the adult mammalian nervous system, where neuronal and axonal growth normally occurs, is the olfactory system and continuous replacement of the olfactory neurons is maintained throughout life of the individual [Farbman, 1986, 1988, 1994].

Investigation of the olfactory system is particularly intriguing for glycobiologists for at least three reasons: (1) Glycoconjugates play a crucial role in the development of the olfactory system. (2) Glycoconjugates are involved in continuous regeneration of the olfactory neurons, i.e. in neuronal proliferation, neurite outgrowth, fasciculation and synapse formation. (3) Glycoconjugates are important in recognition, discrimination, transfer and processing of odorant information. An enormous variety of glycoconjugates, i.e. glycoproteins, glycolipids, glycosaminoglycans and proteoglycans, has been tracked down in the olfactory system by different methods of glyco- and immunohistochemistry as well as molecular biology. Olfactory-specific glycoconjugates as well as glycoconjugates without tissue specificity have been found in the different parts of the olfactory system, in various subcellular localization or in the extracellular matrix. 
Fig. 2. Schematic drawing of the olfactory epithelium [according to Hees and Sinowatz, 1992]. A=Olfactory neuron; $1=$ dendritic knob; $2=$ sensory cilia; $3=$ perikaryon with nucleus; $4=$ axon; $\mathrm{B}=$ supporting cell with microvilli; $\mathrm{C}=$ basal cells.

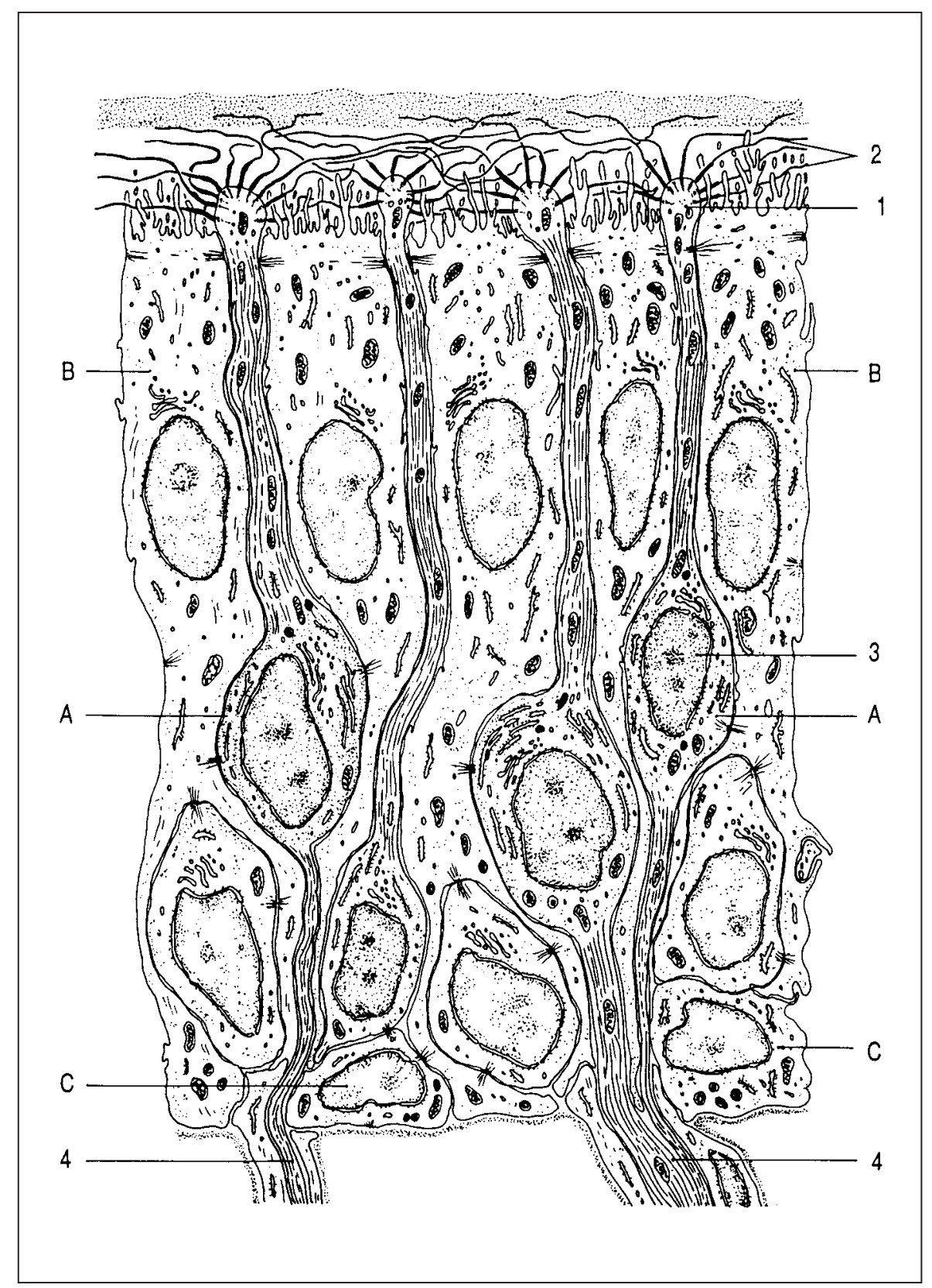

\section{Lectin Labeling of the Olfactory System}

\section{Lectin Labeling and Olfactory Anatomy}

The expression of various sugar moieties in the main and accessory olfactory system has been studied intensely by labeling with a battery of lectins. Although the actual intrinsic role of plant lectins is still a matter of debate [Rüdiger, 1998], they are well-appreciated laboratory instruments for investigating the presence of distinct sugar determinants, as similarly documented in this issue by Brinck et al. [1998], Danguy et al. [1998] and Zschäbitz [1998]. Whereas the chapter of Villalobo and Gabius [1998] deals with the biochemical events of signaling, this contribution focuses on the histochemical level. Table 1 gives an overview on studies using lectin binding and documents that this method is a powerful tool to identify anatomical subdivisions of the olfactory system in different species. Lectin-reactive epitopes can be found in all parts 
Fig. 3. Schematic diagram of the synaptic organization of the olfactory bulb. $1=$ Olfactory axons; $2=$ glomerular layer; $3=$ mitral cells; $4=$ granule cells; $5=$ superficial tufted cells; $6=$ deep tufted cells; $7=$ periglomerular cells; $8=$ superficial short axon cells; $9=$ deep short axon cells; $10=$ fibers to anterior commissure; $11=$ fibers to anterior olfactory nucleus; $12=$ fibers to lateral olfactory tract; $13=$ fibers to mesencephalon: $14=$ fibers from lateral olfactory tract.

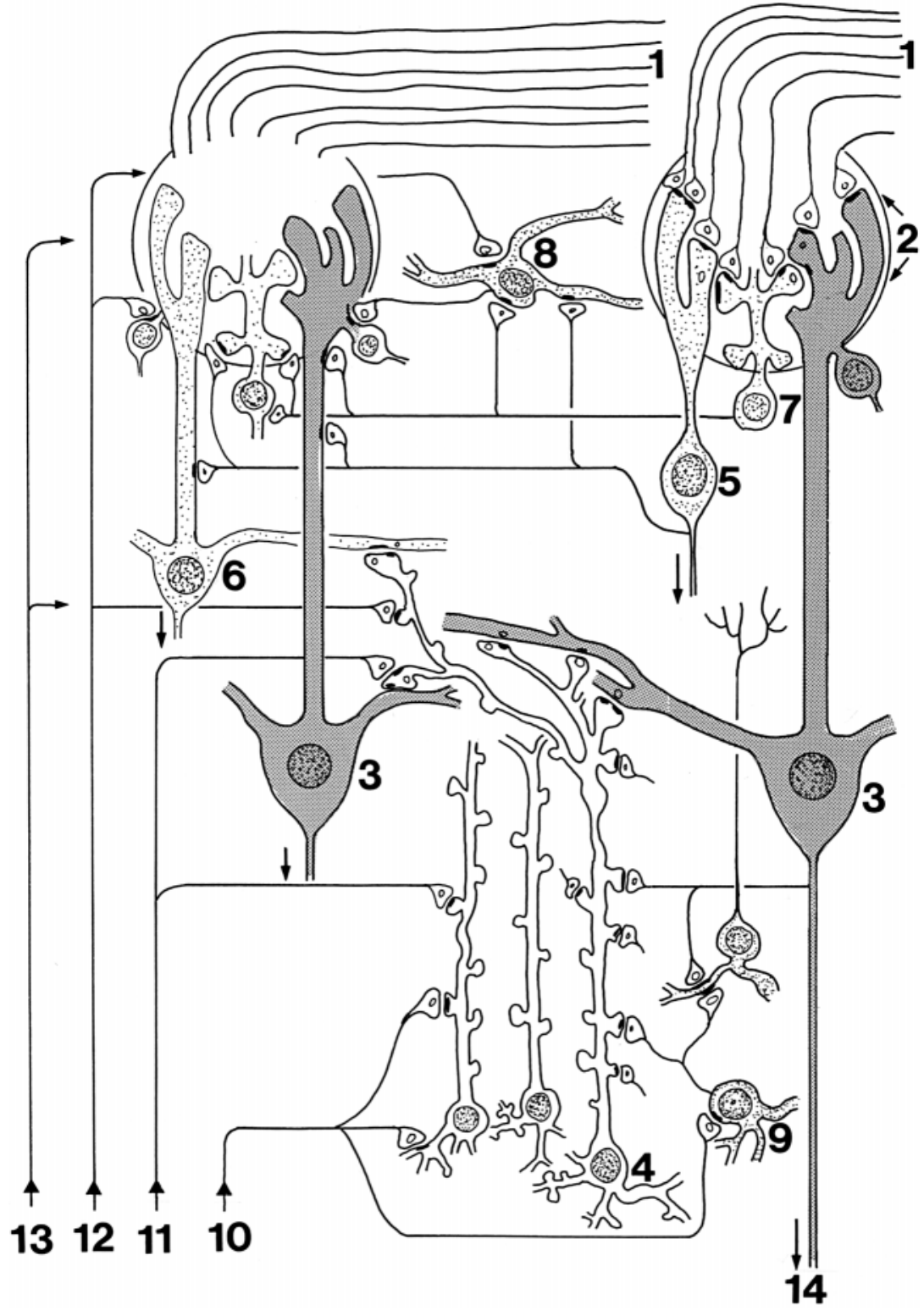

of the olfactory system, including neurons, supporting cells, basal cells, olfactory bulbs, Bowman glands and mucus.

Certain sugar moieties are expressed throughout the olfactory system, as has been shown with the N-acetylgalactosamine-specific lectin soybean agglutinin (SBA). This lectin labels all parts of the olfactory system in Xenopus, i.e. the olfactory and vomeronasal epithelia, the olfactory and accessory olfactory nerves and the olfactory and

Glycobiology of the Olfactory System the accessory olfactory bulbs [Key and Giorgi, 1986b]. Other lectins distinguish the main and accessory olfactory system, for example Vicia villosa agglutinin (VVA) or Bandeiraea simplicifolia agglutinin I (BSA I). These lectins, specific for terminal $\mathrm{N}$-acetylgalactosamine and galactose, recognize cell surface carbohydrates in the vomeronasal system but not in the main olfactory system of the opossum [Shnayder-Shapiro et al., 1995]. Recently, further subdivisions of the accessory olfactory bulb have been docu- 
Table 1. Lectin binding studies of the main and accessory olfactory systems grouped according to chronological order

\begin{tabular}{|c|c|c|}
\hline Species & Lectin(s) & References \\
\hline Mouse & Con A & Smuts [1977] \\
\hline Garfish & Con A & Cole and Elam [1983] \\
\hline Rat & BSA I, Con A, LCA, MPA, PHA, PNA, PWM, WGA, TPA & Hempstead and Morgan [1983] \\
\hline Frog & Con A & Chen and Lancet [1984] \\
\hline Rat & Con A, LTA, RCA I, RCA II, SBA, UEA I, WGA & Pfenninger et al. [1984] \\
\hline Rat & $x^{\prime}$ & Scott and Pemberton [1984] \\
\hline Mouse & WGA & Broadwell and Balin [1985] \\
\hline Xenopus & SBA & Key and Giorgi [1985] \\
\hline Hamster & WGA & Schoenfeld et al. [1985] \\
\hline Rat & WGA & Shipley [1985] \\
\hline Rat & PHA & Zahm and Heimer [1985] \\
\hline Rat & WGA & Baker and Spencer [1986] \\
\hline Frog & Con A, WGA & Chen et al. [1986] \\
\hline Rat & Con A & Collins and Surtees [1986] \\
\hline Rat, mouse & SBA & Key and Giorgi $[1986 a, b]$ \\
\hline Human, rat, mouse, dog & $\begin{array}{l}\text { AAA, BSA, I-B, BSA II, Con A, DBA, LCA, LFA, LTA, } \\
\text { PNA RCA I, SBA, VVA, UEA I }\end{array}$ & Nakagawa et al [1986] \\
\hline Rat & PHA & Woolf et al. [1986] \\
\hline Rat & Con A & Edwards et al. [1987] \\
\hline Rat & PHA & Heimer et al. [1987] \\
\hline Catfish & Con A, PNA, WGA & Kalinoski et al. [1987] \\
\hline Rat & PHA & Ichikawa [1988] \\
\hline Mouse & DBA & Plendl and Schmahl [1988a, b] \\
\hline Rat & UEA I & Barber [1989] \\
\hline Chick & Con A, DBA, PNA, RCA I, SBA, UEA I, WGA & Croucher and Tickle [1989] \\
\hline Lizard & Con A, PNA, SBA, WGA, WPA & Ferri and Liquori [1989] \\
\hline Mouse & Con A, DBA, PNA, SBA, UEA I, WGA & Lundh et al. [1989] \\
\hline Rhesus monkey & Con A & Menco [1989] \\
\hline Mouse & DBA, LPA, PNA, SBA, UEA I, WGA & Mendoza et al. [1989] \\
\hline Rat & Con A & Polak et al. [1989] \\
\hline Squirrel monkey & WGA & Sadikot et al. [1990] \\
\hline Rat & BSA I-B ${ }_{4}$, DBA, EEA, PNA, SBA, SJA, UEA I, VVA, WFA & Silverman and Kruger [1990] \\
\hline Salamander, hamster, mouse & $\begin{array}{l}\text { BPA, BSA I, Con A, DBA, DSA, LFA, LPA, LTA, MPA, PNA, SBA, } \\
\text { UEA I, WGA }\end{array}$ & Foster et al. [1991] \\
\hline Eel & BSA I, BSA I-B ${ }_{4}$, DBA, SBA & Franceschini and Ciani [1991] \\
\hline Human & Con A, DBA, LTA, PNA, SBA, UEA I, WGA & Gheri et al. [1991] \\
\hline Xenopus & SBA & Hofmann and Meyer [1991] \\
\hline Frog & DBA & Key and Akeson [1991a] \\
\hline Rat & PHA & Kott et al. [1991] \\
\hline Rat, golden hamster & DBA, LPA, PNA, SBA, UEA, WGA & Mendoza and Kühnel [1991] \\
\hline Teleostean fishes & Con A, DBA, LTA, PNA, SBA, UEA I, WGA & Pastor et al. [1991] \\
\hline Mouse & SBA & Wysocki and Lepri [1991] \\
\hline Rat & Con A & Farbman [1992] \\
\hline Rat & Con A, PNA, SBA, WGA & Farbman and Buchholz [1992] \\
\hline Salamander & LFA & Foster et al. [1992] \\
\hline Amphibia (Ambystoma, Xenopus) & SBA & Franceschini et al. [1992] \\
\hline Human & Con A, DBA, LTA, PNA, SBA, UEA I, WGA & Gheri et al. [1992] \\
\hline Rat & $\begin{array}{l}\text { BSA I, BSA II, Con A, DBA, DSL, ECA, JAC, LEA, LCA, PHA, } \\
\text { PNA, PSA, RCA, SBA, SJA, STA, WGA, UEA I, VVA, WGA }\end{array}$ & Ichikawa et al. [1992] \\
\hline Rat & DBA, PNA, SBA, WGA & Menco [1992] \\
\hline Rainbow trout & PWA & Oakley and Riddle [1992] \\
\hline Squirrel monkey & PHA & Sadikot et al. [1992] \\
\hline Dog & UEA I & Salazar et al. [1992] \\
\hline Rat & BSA I, VVA & Takami et al. [1992] \\
\hline Rat & $\mathrm{BSA} \mathrm{I}_{-} \mathrm{B}_{4}$ & Caggiano and Brunjes [1993] \\
\hline Shark & SBA, BSA I, BSA I-B & Franceschini and Ciani [1993a] \\
\hline
\end{tabular}


Table 1 (cont.)

\begin{tabular}{|c|c|c|}
\hline Species & Lectin(s) & References \\
\hline Newt (Triturus) & $\begin{array}{l}\text { BSA I, BSA I-B }{ }_{4} \text {, Con A, DBA, LCA, PHA, PNA, PSA, RCA I, } \\
\text { SBA, SJA, UEA I, WGA }\end{array}$ & Franceschini and Ciani [1993b] \\
\hline Salamander & DSA, LFA & Getchell et al. [1993] \\
\hline Mouse & DBA & Key and Akeson [1993] \\
\hline Human & SBA, UEA I & Nagao et al. [1993] \\
\hline Rainbow trout & Con A, DBA, PHA, PNA, PWA, SBA, UEA I, WGA & Riddle et al. [1993] \\
\hline Golden hamster & $\begin{array}{l}\text { BSA I, BSA II, Con A, DBA, DSL, ECL, LEL, PNA, PSA, SBA, SJA, } \\
\text { STA, UEA I, VVA, WGA }\end{array}$ & Taniguchi et al. [1993] \\
\hline Rat & BSA I, LEA, SBA & Franceschini et al. [1994] \\
\hline Mouse & 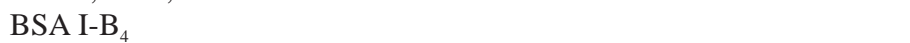 & Htain et al. [1994] \\
\hline Rat & BSA I, VVA & Ichikawa et al. [1994a, b] \\
\hline Rat & UEA I & Pellier and Astic [1994] \\
\hline Rat & BSA I & Schwob et al. [1994] \\
\hline Rat & 21 lectins & Saito et al. [1994] (in Japanese) \\
\hline Rat & BSA I-B $_{4}$, DBA, DSA, VVA, WGA & Takami et al. [1994] \\
\hline Mouse & MAA, SNA & Uena et al. [1994] \\
\hline Rat & TPA, UEA I & Pestean et al. [1995] \\
\hline Opossum & BSAI, VVA & Shapiro and Halpern [1995] \\
\hline Rat & BSA I-B 4 & Takami et al. [1995] \\
\hline Turtle & BSAI, DBA, LEA, SBA, SJA & Franceschini et al. [1996] \\
\hline Honeybee, locust & DSA & Hahnlein et al. [1996] \\
\hline Frog & SBA & Meyer et al. [1996] \\
\hline Rat & UEA I & Pellier et al. [1996] \\
\hline Opossum & 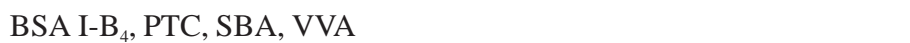 & Shapiro et al. [1996] \\
\hline Rat & Lotus lectin & Stewart and Touloukian [1996] \\
\hline Lamprey & BSA I & Tobet et al. [1996] \\
\hline Transgenic mouse (H-OMP-LacZ-6) & DBA & Treloar et al. [1996] \\
\hline Rat & WFA & Koppe et al. [1997] \\
\hline Frog & SBA & Meyer et al. [1997] \\
\hline Mouse & DBA & Treloar et al. [1997] \\
\hline Rat & 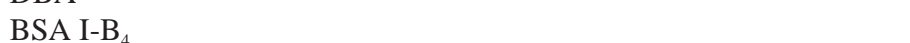 & Wu et al. [1997] \\
\hline Mink & $\mathrm{BSA} \mathrm{I}^{-\mathrm{B}_{4}}$, UEA I, VVA & Salazar et al. [1998] \\
\hline
\end{tabular}

AAA = Aleuria aurantia agglutinin; BPA=Bauhinia purpurea agglutinin; BSA I=Bandeiraea simplicifolia agglutinin I; Con A=concanavalin A; DBA = Dolichos biflorus agglutinin; DSA = Datura stramonium agglutinin; ECA = Erythrina cristagalli agglutinin; EEA =Euonymus europaeus agglutinin; JAC = Jacalin $;$ LCA = Lens culinaris agglutinin; LEA = Lycopersicon esculentum agglutinin; LFA = Limax flavus agglutinin; LPA = Limulus polyphemus agglutinin; LTA = Lotus tetragonolobus agglutinin; MAA=Maackia amurensis agglutinin; MPA= Maclura pomifera agglutinin; $\mathrm{PHA}=$ Phaseolus vulgaris agglutinin; $\mathrm{PNA}=$ peanut agglutinin; $\mathrm{PSA}=$ Pisum sativum agglutinin; $\mathrm{PWA}=$ pokeweed agglutinin; RCA I=Ricinus communis agglutinin; SBA = soybean agglutinin; SJA = Sophora japonica agglutinin; SNA = Sambucus nigra agglutinin; STA = Solanum tuberosum agglutinin; TPA = Tetragonolobus purpurea agglutinin; UEA I=Ulex europaeus agglutinin; VVA=Vicia villos a agglutinin; WFA = Wisteria floribund $a$ agglutinin; $\mathrm{WGA}=$ wheat germ agglutinin .

mented in the mink by labeling with the lectins BSA I and VVA [Salazar et al., 1998]. Moreover, differences in oligosaccharide cellular content and distribution in basal cells, supporting cells and olfactory neurons have been documented with lectins like for example the $\alpha$ - $L$-fucosespecific Ulex europaeus agglutinin I (UEA I) in humans and rats [Barber, 1989].

Glycobiology of the Olfactory System

\section{Lectin Labeling and Olfactory Development}

The selective binding of lectins to cells of the olfactory system suggests that specific glycoconjugates may have a role in development and growth. The primitive olfactory placodes already express mannosyl and/or glucosyl residues as shown with the lectin concanavalin A (Con A) in the mouse [Smuts, 1977]. A correlation between lectin binding and the development of the olfactory system has

Acta Anat $1998 ; 161 \cdot 234-253$ 
been described by Plendl and Schmahl [1988a, b]. They found that in the NMRI mouse the Dolichos biflorus agglutinin (DBA), specific for $\mathrm{N}$-acetyl- $D$-galactosamine, labeled single olfactory neurons from gestation day 14 onward, i.e. the time when synaptic contacts between axon terminals and mitral cells were established for the first time (fig.4). From gestation day 17 onward the number of DBA-positive neurons increased significantly (fig. 5-7). At the level of the rostral olfactory bulb a significant labeling of nerve fibers was observed (fig. 8). Within the olfactory bulb glomeruli became lectin-positive for the first time (fig. 9). An unusual result of this study was that endothelium of capillaries in close contact with either undifferentiated olfactory epithelium or undifferentiated neural tissue was strongly positive for DBA. After final differentiation of the neuroepithelium the DBA affinity of the endothelium disappeared (fig. 4, 5). The membrane glycoconjugates identified by DBA binding possibly play a role in the formation of a mosaic olfactory projection of the olfactory system. Obviously, a distinct subset of neurons exhibits a topographical projection from the olfactory epithelium to the olfactory bulb. Moreover, it appears that the outer nerve fiber layer in the rostral olfactory bulb may play a crucial role in the guidance and fasciculation of olfactory sensory axons [Key and Akeson, 1993]. Similar results have been obtained with other lectins like Lotus tetragonolobus agglutinin, specific for terminal $L$-fucose and $\mathrm{N}$-acetylglucosamine, and also in other species [Stewart and Touloukian, 1996].

Another aspect of olfactory development has been shown by labeling with the lectin VVA. This lectin binds to distinct glycoconjugates which have been suggested to be involved in the formation and maturation of neuronal connections [Ichikawa et al., 1994a, b]. In the olfactory system of the rat, VVA inhibits the fasciculation of vomeronasal axons, as shown in vomeronasal organ culture. Timing and duration of the presence of VVA are related to the inhibition of fasciculation of the axons. Glycoconjugates that bind VVA may therefore be responsible for fasciculation of the developing olfactory nerve [Ichikawa et al., 1994a]. Similarly, the levels of expression of peanut agglutinin (PNA) binding sites in the developing olfactory system of the chick correlate with the degree of fasciculation of the olfactory nerve [Gong and Shipley, 1996].

\section{Lectin Labeling and Olfactory Function}

During the transient interaction of odorant molecules with the olfactory neurons a cascade of signals including receptor potentials and release of neurotransmitters is induced leading to the perception of an odor [Breer, 1991, 1996]. The initial event in olfaction consists of the tempo- rary binding of the odorant to the olfactory receptor neuron. It has been proposed that odorant receptor molecules are glycoproteins [Chen et al., 1986; Breer, 1991].

Binding of specific lectins clearly correlates with the function of the olfactory neurons. The mucosensory compartments of chemosensory epithelia, the sites where receptor-specific events associated with transduction occur, have been found to be rich in glycoconjugates. Lectin binding studies of vomeronasal receptor neurons in snakes have demonstrated that their dendritic terminals have a prominent glycocalyx [Takami and Hirosawa, 1987; Takami et al., 1995]. The ciliary glycocalyx of neurons of the main olfactory system in different vertebrates including salamanders, hamsters and mice contain sialic acid residues [Foster et al., 1992] and N-acetylglucosamine residues [Getchell et al., 1993]. By labeling with BSA I, which is specific for $\alpha$-galactose residues, it was demonstrated that the mucomicrovillar complex in rats is composed of islet-like structures with a high-density $\alpha$-galactose core that can be resolved into sensory and mucoid components both containing glycoconjugates with terminal $\alpha$-galactose [Takami et al., 1995].

Observations made by lectin binding can be considered as an indication that glycoconjugates are involved in the chemoreception of olfactory stimuli. The presence of specific glycoconjugates might be related to transduction of the odorous message into a nervous signal and lectins can be used as ligands for characterization and isolation of odorant receptors. Treatment of olfactory cilia with certain lectins, notably Con A, PNA, and wheat germ agglutinin (WGA),

Fig. 4. Olfactory epithelium of an NMRI mouse (embryonic day 14) labeled with DBA: a single neuron is positive for the lectin. Endothelium of capillaries adjacent to the olfactory epithelium is also DBA-positive. $\times 875$.

Fig. 5. Olfactory epithelium of an NMRI mouse (postnatal day 1) labeled with DBA: neurons located in the upper portion of the neuroepithelium are DBA-positive. Endothelium of capillaries is no longer labeled. $\times 950$.

Fig. 6. Olfactory epithelium of an NMRI mouse (embryonic day 15) labeled with DBA: DBA-positive neurons are scattered throughout all layers of the neuroepithelium. $\times 875$.

Fig. 7. Olfactory epithelium of an NMRI mouse (postnatal day 5) labeled with DBA: numerous receptor neurons exhibit lectin binding. $\times 875$.

Fig. 8. Olfactory bulb of an NMRI mouse (postnatal day 2) labeled with DBA: the outer nerve layer of the rostral olfactory bulb strongly reacts with DBA. $\times 760$.

Fig. 9. Olfactory bulb of an NMRI mouse (postnatal day 5) labeled with DBA: olfactory glomeruli within the olfactory bulb are strongly positive. $\times 1,400$. 

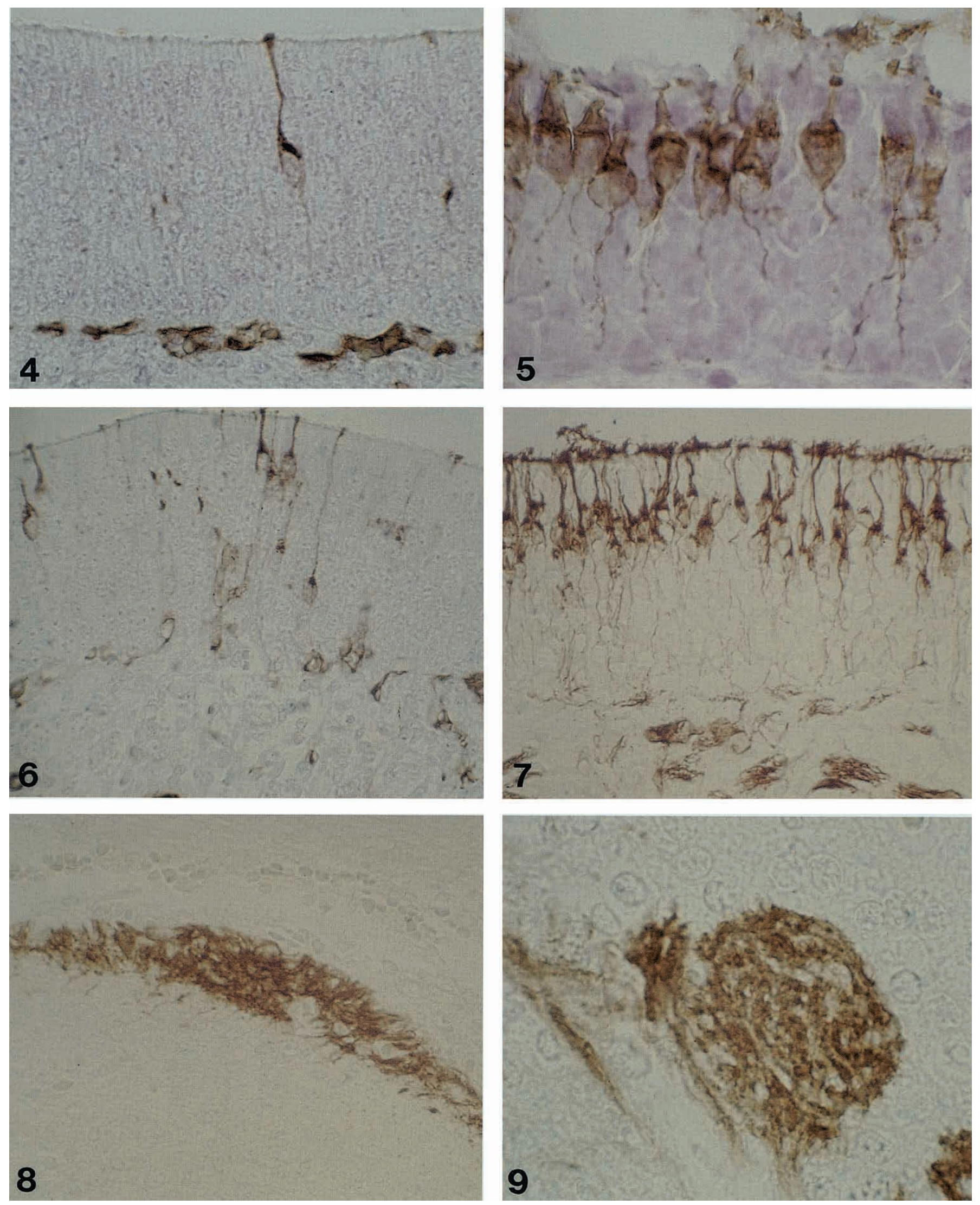
significantly reduces the responses induced by certain odorants [Breer, 1991]. The effects are specific because the appropriate hapten sugars prevent the actions of lectins. Moreover, the lectins Con A and WGA were found to specifically interact with olfactory membranes and to affect the ability of their receptors to bind $L$-alanine and $L$-arginine, both effective stimuli that elicit olfactory electrophysiological responses [Kalinoski et al., 1987]. For certain odorants the amplitude of the electroolfactogram in rats was reduced after the olfactory epithelium was treated with the lectin Con A. This lectin disables an olfactory receptor molecule which normally responds to the alkyl moiety of odorants in a particular size range. Thus, Con A reveals olfactory receptors which discriminate between alkane odorants on the basis of size [Polak et al., 1989].

Labeling with SBA demonstrated a functional distinction between SBA-positive and SBA-negative neurons in Xenopus. The SBA-negative ones are utilized to detect airborne odors, whereas major SBA-positive neurons serve a role in the perception of water-dissolved molecules. SBA-negative structures detect small, volatile molecules, SBA-positive olfactory structures are involved in detecting large, water dissolved molecules, e.g. pheromones which are of relevance for intra- or interspecific communication [Hofmann and Meyer, 1991].

\section{Endogenous Lectins in the Olfactory System}

As has been shown in the preceding paragraph, exogenous lectins enjoy large popularity as tools to localize defined carbohydrate structures in the olfactory system. A more recent method, termed 'reverse lectin histochemistry' using carrier-immobilized glycoligands, like for example neoglycoproteins, enables the visualization of endogenous lectins [Danguy et al., 1991; Gabius, 1991, 1997a, b; Gabius and Bardosi, 1991; Gabius et al., 1993; Kannan and Nair, 1997; Kayser and Gabius, 1997; Danguy et al. 1998]. The binding of distinct parts of the carbohydrate chains of cellular glycoconjugates by endogenous lectins is considered to be an important means of facilitating molecular recognition. An important mechanism for guiding cell-cell interactions is through the recognition of specific cell surface glycoconjugates by endogenous lectins [for a collection of laboratory protocols and recent reviews, see Gabius and Gabius, 1993, 1997].

The first to use neoglycoproteins in order to characterize endogenous lectins in the olfactory system in mice and bats were Lincoln et al. [1991] and Schwaighofer-Breuer [1992]. Endogenous lectins were found to be localized in receptor cells and supporting cells of the main olfactory epithelium and mitral as well as granule cells in the olfac- tory bulb. By chemically glycosylating bovine serum albumin (BSA) a panel of probes can be produced which only differs in their sugar part. Receptor cells in the main olfactory epithelium displayed strong binding for the neoglycoproteins lactose-BSA, asialofetuin, melibiose-BSA and xylose-BSA. The neuroepithelial basal membrane specifically bound the neoglycoproteins lactose-BSA, maltoseBSA, cellobiose-BSA and xylose-BSA. Mitral cells in the main olfactory bulb strongly reacted with the neoglycoproteins lactose-BSA, cellobiose-BSA, mannose-6-phosphate-BSA, xylose-BSA and fucoidan-BSA. Thus, different cells of the olfactory system of the mouse were shown to bind $\alpha$ - and $\beta$-galactosides, $\alpha$-and $\beta$-glucosides, $\beta$-xyloside, $\mathrm{N}$-acetylglucosamine, $\mathrm{N}$-acetylgalactosamine and the sulfated polysaccharide fucoidan [Lincoln et al., 1991]. In the bat the existence of $\beta$-galactoside-specific proteins in cells of the olfactory epithelium, olfactory bulb and Bowman glands was revealed by the use of the biotinylated glycoproteins asialofetuin and asialotransferrin. In contrast to the mouse, except for $\alpha$-mannoside and $\beta$-xyloside-specific proteins, no further endogenous lectins could be tracked down in the olfactory system of the bat [SchwaighoferBreuer, 1992].

There are discrete subpopulations of olfactory neurons, each of which selectively expresses terminal carbohydrate moieties containing different sequences with galactose as structural part (as has been shown by labeling with exogenous lectins; see table 1). Such an epitope is considered to be a potential ligand for members of the rather abundant family of galectins [Gabius, 1997a, b; Kaltner et al., 1997; Kaltner and Stierstorfer, 1998; Zanetta, 1998]. Interestingly, it is possible that the same $\beta$-galactoside sequence can display more than one energetically favored conformation and that a galectin has been shown to perform differential conformer selection relative to a plant agglutinin [von der Lieth et al., 1998]. Galectin-1, previously known as RL 14.5 or L 14, can also be such a target [Mahanthappa et al., 1994; Puche and Key, 1995]. Immunohistochemical and in situ hybridization analyses in rats revealed expression of galectin-1 by primary sensory olfactory neurons during the major embryonic period of axogenesis as well as in maturity. In the olfactory bulb of adults galectin- 1 is expressed by both second order projection neurons and interneurons. Mitral cells, the main projection neurons of the olfactory bulb, begin to express this lectin soon after genesis. Galectin-1 binds and colocalizes with a member of the laminin family and a 1B2 immunoreactive olfactory glycolipid. The former is present in the extracellular matrix of the axonal path leading to synaptic targets in the olfactory bulb, the latter is expressed on the surface of nascent 
olfactory axons originating from neuronal cell bodies in the olfactory epithelium. Galectin-1 supports axonal adhesion to the extracellular matrix and thus represents an adhesion molecule [Mahanthappa et al., 1994; Puche and Key, 1995]. Cell surface carbohydrates that contain terminal galactose have previously been implicated in primary sensory axon growth in the rodent olfactory system. It has been speculated that galectin-1 is responsible for fasciculating the galactose-expressing axons in the olfactory pathway and that it promotes fasciculation by cross-linking adjacent axons. Recently Key and Puche [1997] succeeded in proving that in galectin-1 null mutant mice a subpopulation of axons failed to navigate to their target site in the olfactory bulb. This is the first notable phenotypic effect observed in knockout mice and indicates that galectin-1 guides axons during development.

\section{Glycoproteins as Surface Adhesion Molecules in the Olfactory System}

\section{The Immunoglobulin Superfamily}

Members of the immunoglobulin superfamily expressed in the olfactory system are the neural cell adhesion molecules (N-CAMs) and the glycoproteins L1, OCAM, Thy-1, and LIG-1.

The neural cell adhesion molecules N-CAMs are sialoglycoproteins. They are involved in cell-cell interactions in the nervous system and have been implicated in multiple functions during neuronal pattern formation. Posttranslational modifications such as glycosylation can introduce considerable diversity in N-CAM structure. The olfactory system expresses several specific glycoforms of N-CAM: three unique N-CAM forms present on primary sensory olfactory axons were shown by labeling with the lectin DBA and two monoclonal antibodies, 9OE and 3A6 [Key and Akeson, 1990, 1991a, b]. One of them, the embryonic form of N-CAM was only observed on the majority of basal cells, the precursor cells of olfactory neurons and probably immature neurons. The presence of N-CAM in adulthood on neuronal precursor cells may be a reason for its remarkable regenerative capacity [Miragall et al., 1988]. A mutation of N-CAM in mice produces a phenotype dominated by an undersized olfactory bulb and accumulation of precursors in the subependymal layer [Ono et al., 1994].

The migration of neuronal precursors to their final locations and the projection of axons to their appropriate targets are two critical events in neural development that require cell-cell and cell-matrix interactions. The migration of luteinizing hormone-releasing hormone (LH-RH) neurons via the olfactory system is probably one of the best examples for the highly specific function of N-CAM in olfactory neuronal and axonal guidance. Anatomically LH-RH neurons are diffusely distributed in the brain. Interestingly and also difficult to understand, LH-RH neurons originate in the olfactory placode and vomeronasal organ and migrate to the brain during embryogenesis [Pellier and Astic, 1994]. Immunohistochemical studies indicate that glycoconjugates in the vomeronasal nerve may serve as guides for migrating LH-RH neurons [Wray et al., 1994]. The vomeronasal nerve can be divided into four spatially distinct subpopulations of fibers. One subset, composed of caudal fibers that terminate in the lamina terminalis, selectively expresses a highly polysialated form of N-CAM, termed PSA-N-CAM. LH$\mathrm{RH}$ neurons migrate in contact with these branches of the vomeronasal nerve [Yoshida et al., 1995]. In the genetic arhinencephalic mouse the migration of LH-RH neurons is arrested [Naruse et al., 1994].

Another member of the immunoglobulin superfamily with a similar expression pattern as N-CAM is L1. It is a cell surface glycoprotein that promotes neurite outgrowth on $\mathrm{L}^{+}$partner cells. $\mathrm{L} 1$ is expressed in the olfactory nerve and on the olfactory receptor neurons commencing with the earliest olfactory axon outgrowth. The expression pattern suggests that L1, like N-CAM, is associated with extension and fasciculation of olfactory axons [Whitesides and LaMantia, 1995; Gong and Shipley, 1996].

OCAM (R4B12 antigen) is an axonal surface glycoprotein expressed by a subset of both olfactory and vomeronasal axons in a zone-specific manner. OCAM is a novel adhesion molecule also belonging to the immunoglobulin superfamily with structural homology to N-CAM. In both the main and the accessory olfactory systems of mice OCAM messenger RNA (mRNA) is expressed by sensory neurons in restriced zones and OCAM protein-expressing axons project to the glomeruli of the corresponding zone in the bulb. This suggests that OCAM may play a role in selective fasciculation and zone-to-zone projection of the primary olfactory axons [Yoshihara et al., 1997].

Thy-1 is a major glycoprotein of the surface of mature neurons. This member of the immunoglobulin superfamiliy has been shown to bind tissue plasminogen activator with high affinity. Expression of this neuronal cell surface glycoprotein has been found during the development of the olfactory bulb in mice and rats by in situ hybridization and immunohistochemistry. Thy-1 mRNA was detected before birth on mitral cells as they formed a distinct layer and grew dendrites. Thy-1 protein on the other hand was detectable only two days later on a group of mitral cells immediately adjacent to the point of entry of the olfactory 
nerve. Results indicate that Thy- 1 is under posttranscriptional control, i.e. expression of Thy-1 does not simply follow expression of its mRNA, but requires some further signal. Analyses of the growth of the mitral cell axons in the olfactory tract suggest that the signal for the appearance of Thy-1 probably is the cessation of olfactory axonal growth. Therefore, the function of Thy-1 may be related to the guidance of axons [Xue et al., 1990].

LIG-1 is an integral membrane glycoprotein of the immunoglobulin superfamily, containing an extracellular region with several glycosylated sites. In situ hybridization analyses in the mouse showed LIG-1 gene expression to be predominantly in the brain, restricted to a small subset of glial cells such as those of the cerebellum and nerve fiber layer of the olfactory bulb. On the basis of its structural features and expression pattern LIG-1 function is supposed to be a cell-type-specific cell adhesion molecule or receptor on the glial surface controlling olfactory neuroglial differentiation [Suzuki et al., 1996].

\section{Cadherins}

The cadherins are a family of membrane glycoproteins including E-, N- and PB-cadherins. Whereas the distribution of E-cadherin varies in accordance with changes in olfactory axon development [Whitesides and LaMantia, 1996], N-cadherin is expressed throughout the entire olfactory nerve in human fetuses suggesting that the growth of olfactory axons to their target may be mediated by these adhesion molecules [Simonneau et al., 1992; Norgren and Brackenbury, 1993]. PB-cadherin is responsible for $\mathrm{Ca}^{2+}$ dependent cell adhesion. Its mRNA has been found in the inner granular layer of the olfactory bulb in the rat [Sugimoto et al., 1996].

\section{Integrins}

The integrin family of cell adhesion molecules is a series of glycoproteins that recognize a range of cell surface and extracellular matrix-associated ligands. Further structural details of integrins are presented in this issue by Kaltner and Stierstorfer [1998]. As examined by in situ hybridization in Xenopus the integrin $\alpha 6$ subunit, a member of a subfamily of laminin receptors, is expressed early in development in a variety of neural derivatives including the olfactory placodes. This indicates that $\alpha 6$ integrin may be critical for the early development of the olfactory system [Lallier et al., 1996].

\section{$2 B 8$ and $5 B 4$ Antibodies}

The first-identified cell surface components of olfactory receptor neurons were glycoproteins recognized by the antibody 2B8. Reactivity was found on cells of the main olfactory system only, namely on a group of olfactory receptor neurons as well as in the glomerular and olfactory nerve layer of the olfactory bulb. Lectin binding of the 2B8 antigens indicated presence of sialic acid and $D$-galactosyl components. The subset of neurons expressing the $2 \mathrm{~B} 8$ glycoprotein was suggested to be an odor-processing group or a certain age class [Allen and Akeson, 1985]. The monoclonal antibody 5B4 recognizes a membrane glycoprotein in the rat. The larger form of this antigen (185-255 kDa) occurs in the developing nervous system and is present in membranes of growth cones. A smaller form of this antigen $(140 \mathrm{kDa})$ is present in olfactory axons. 5B4 intensely stains a variable proportion of olfactory axons in the mucosa as well as in the olfactory bulb. Based on immunohistochemical data it has been documented that the 5B4 antigen is associated specifically with neuronal and axonal growth, i.e. neurons that are generating neurites [Wallis et al., 1985].

\section{Follistatin and Collapsin-1}

Follistatin is a secreted glycoprotein that has been shown to act as a potent neural inducer during early development of amphibians and rodents [Connolly et al., 1995]. Abundant follistatin mRNA expression is localized in several areas of the olfactory bulb as well as in other parts of the brain including the cerebral cortex and few thalamic nuclei [Macconell et al., 1996].

Collapsin-1 is a secreted glycoprotein and a member of the semaphorin family of signalling molecules that inhibits the extension of specific growth cones in vitro and acts as repellent for growing spinal sensory axons. In the early chick brain collapsin-1 is expressed in specific regions including the olfactory bulb, the retina and the diencephalon. The distribution of collapsin mRNA is consistent with it playing a role in preventing premature entry of sensory axons into the olfactory bulb [Shepherd et al., 1996; Kobayashi et al., 1997].

\section{TAG-1, BIG-1, BIG-2 and Neurotrimin}

The transient axonal glycoprotein, TAG-1, is involved in adhesion and neurite outgrowth. Immunohistochemical studies indicated that TAG-1 is expressed on a subset of fibers of the vomeronasal nerve. TAG-1, together with $\mathrm{N}-\mathrm{CAM}$, thus may be involved in directing the migration of LH-RH neurons [Yoshida et al., 1995].

cDNA encoding a novel truncated form of the gene BIG-2 has been cloned from the vomeronasal organ of mice. The related proteins BIG-1 and BIG-2 possess a C-terminal glycosylphosphatidylinositol anchor, immuno- 
globulin domains and fibronectin repeats. They are related to the glycoprotein TAG-1 and may play a role in the organization of the vomeronasal and olfactory neuroepithelia [Mimmack et al., 1997].

Another glycosylphosphatidylinositol-anchored protein is neurotrimin. This differentially expressed neural cell adhesion molecule is found at high levels in the olfactory bulb, neural retina, spinal cord and hippocampus. Together with other members of the glycosylphosphatidylinositol anchored protein family it provides diversity to the surface of different neuronal populations that could be important in the specification of neuronal connectivity [Struyk et al., 1995].

\section{Nerve Growth Factor-Inducible Large External \\ Molecule}

The nerve growth factor-inducible large external (NILE) molecule is a 230,000-dalton glycoprotein. NILE-related glycoproteins are present during the early phases of neuronal fiber tract formation. Postnatally they can be found in parts of the nervous system including the olfactory bulbs which undergo major histogenesis during the postnatal period. A role for the NILE glycoprotein in medating nerve fiber fasciculation has been suggested [Stallcup et al., $1985]$.

\section{Neuropilin}

Neuropilin is a cell surface glycoprotein that was first identified in Xenopus tadpole nervous tissue and then in chicken and mice. The primary structure is highly conserved among these vertebrates. Neuropilin has been found to be expressed in the olfactory axons [Satoda et al., 1995]. It was recently identified as a receptor for collapsin-1, a molecule of the olfactory extracellular matrix [Fujisawa et al., 1997; Kolodkin et al., 1997].

\section{Rxt1}

The $\mathrm{Na}^{+} / \mathrm{Cl}^{-}$-dependent glycosylated 97 - to $116-\mathrm{kDa}$ protein Rxt1 is expressed selectively in the central nervous system. Rxt1 is a so-called orphan transporter and high levels of Rxt1 are found in various locations including the olfactory bulb [Masson et al., 1995]. Location suggests that Rxt1-positive neurons might correspond to glutaminergic neurons and subsets of GABAergic neurons [Masson et al., 1996; further details on orphan transporters, see Villalobo and Gabius, 1998].

\section{Ber-EP4 Antibody}

The Ber-EP4 antibody detects a 34,000 molecular weight membrane glycoprotein which is expressed by cells of the olfactory plate in humans. Expression of this antigen continues in neurons arising from these cells, i.e. olfactory sensory neurons and LH-RH neurons. This antigen disappears from the LH-RH neurons, but is preserved in the olfactory primary sensory nerve throughout postnatal life. Except for the neurons arising from the olfactory plate no other human neurons express this antigen during the course of development [Okabe et al., 1996].

\section{Telencephalin}

Localization of a telencephalon-specific glycoprotein, telencephalin, was found in the olfactory bulb of the rabbit. The glycoprotein was expressed in the plasma membrane, Golgi apparatus and multivesicular bodies of granule cells which are local circuit interneurons in the bulb. The significance of this finding is currently unknown [Oka et al., 1990; Murakami et al., 1991].

\section{Glycolipids as Surface Adhesion Molecules in the Olfactory System}

\section{Antibodies}

$\mathrm{CC}$ monoclonal antibodies react with specific $\mathrm{N}$-acetylgalactosamine-containing glycolipids. In the rat embryo, $\mathrm{CC} 1$ antigens are expressed throughout the vomeronasal olfactory neurons and on vomeronasal nerves. Beginning approximately at birth and continuing into adults, CC1 expression is spatially restricted in vomeronasal neurons to centrally located cell bodies. In the postnatal accessory olfactory bulb, CC1 is expressed in the nerve layer and glomeruli but only in the rostral half of this area. These data suggest that $\mathrm{CC} 1$ glycolipids may participate in the targeting of axons from centrally located vomeronasal neurons to rostral glomeruli in the accessory olfactory bulb. In contrast CC2 antibodies which recognize complex $\alpha$-galactosyl and $\alpha$-fucosyl glycolipids react with all vomeronasal cells and vomeronasal nerves and do not distinguish rostral from caudal regions of the accessory olfactory bulb, nor are the CC2 glycoconjugates developmentally regulated [Tobet et al., 1993].

The presence of another glycolipid, the CC6 glycolipid, is restricted to a subset of neurons in the accessory olfactory system and their projections in the accessory olfactory bulb as well as to a subset of neurons in the main olfactory epithelium. The expression of CC6 implies that there are at least two distinct regions of the rodent accessory olfactory bulb and that glomeruli in either segment may receive input from only a restricted subset of neurons in the vomeronasal organ [Schwarting et al., 1992, 1994]. In 
this issue, importance of glycosphingolipid expression is further elaborated with respect to malignancy by Hakomori [1998].

\section{B2 Antibody}

Another monoclonal antibody raised in order to identify developmentally regulated glycolipids was $1 \mathrm{~B} 2$ that reacts with lacto-N-glycosyl ceramides in rats. $1 \mathrm{~B} 2$ is highest at the luminal surfaces of olfactory neurons throughout the vomeronasal organ. 1B2 is also expressed on the surface of a subset of receptor cell bodies, their dendrites and the proximal axons in dorsomedial regions of the main olfactory epithelium [Schwarting and Crandall, 1991].

\section{P-Path Antibody}

P-Path monoclonal antibodies which recognize 9-Oacetylated sialic acids react with cell bodies in the cerebellum, the vomeronasal system and nerve fibers. Migrating LH-RH neurons are associated with P-Path-positive vomeronasal axons in developing rats raising the possibility that these glycoconjugates may provide a chemical guide for migrating neurons [Schwarting and Crandall, 1991; Schwarting et al., 1992; Edwards et al., 1987].

\section{Proteoglycans as Surface Adhesion Molecules in the Olfactory System}

\section{$6 B 4$}

By immunohistochemistry the neural proteoglycan 6B4 was localized in the olfactory epithelium, the olfactory nerve and the cells originating the epithelium and migrating along the olfactory nerve towards the forebrain in chick embryos. The cellular localization of 6B4 together with the binding properties of this proteoglycan with cell adhesion molecules (shown in rat brains) suggests its function in guiding the migration of cells along the olfactory nerve [Nishizuka and Arai, 1996].

\section{H5-PG}

Monoclonal antibodies recognize a membrane-bound heparan sulfate proteoglycan with a core glycoprotein of $140 \mathrm{kDa}$ in the rat brain. H5-PG is a glycoconjugate on axonal surfaces that is involved in axonal outgrowth and synaptogenesis. Its expression is spatially and temporally regulated. High levels of expression were recognized in the olfactory nerves and glomeruli where renewal of both axons and synapses is occurring constantly [Watanabe et al., 1996].

\section{Glypican}

Cell surface proteoglycans like glypican, a $65-\mathrm{kDa}$ glycosylphosphatidylinositol-linked protein, have been implicated in cell responses to growth factors, extracellular matrix and cell adhesion molecules. In situ hybridization showed that glypican is expressed in a subset of structures in the adult nervous system including the olfactory tubercle [Litwack et al., 1994].

\section{Glycoconjugates of the Olfactory Extracellular Matrix}

\section{J1-160/180 Glycoprotein}

Extracellular matrix molecules promote the development of neuronal connections and guide neurite outgrowth. Already during early development extracellular matrix molecules are secreted in the olfactory nerve pathway. The pattern of expression and the activity of extracellular matrix and cell surface adhesion molecules may contribute to the initial assembly of the olfactory pathway. In detail, J1$160 / 180$ is a secreted extracellular matrix glycoprotein and a member of the $\mathrm{J} 1$ family of extracellular matrix glycoproteins with homology to tenascin. It is expressed in the central nervous system exclusively and is derived from glial cells and a subpopulation of neurons. In situ hybridization and immunohistochemical studies revealed localization in the cerebellum, hippocampus and olfactory bulb of rats. J1-160/180 has been shown to be adhesive for glial cells and repellent towards neurons and growth cones. In the olfactory bulb it may be involved in the inhibition of neural interactions [Calof and Lander, 1991; Fuss et al., 1993].

\section{Laminin and Fibronectin}

The multimodular glycoproteins laminin and fibronectin are abundant components of the extracellular matrix, where they provide an adhesive substrate for many cell types. Expression of laminin has been described in the central nervous system including the olfactory system. In the developing olfactory pathway of the rat it displays a unique punctate staining pattern. The distribution of laminin varies in accordance with changes in olfactory axon and growth cone behavior suggesting its role in olfactory neurite outgrowth and guidance. Laminin-axon interactions include integrins and a galectin-1/glycoconjugate adhesion system [Raabe et al., 1997]. In contrast, studies in the rat have documented that fibronectin is absent from the olfactory system in this species [Gong and Shipley, 1996]. 


\section{Proteoglycans}

Glycosaminoglycans constitute major components of the extracellular matrix. The binding properties of glycosaminoglycans to adhesion molecules and other extracellular matrix molecules and to growth factors influence cell behavior such as differentiation and cell adhesion, neurite extension and cell migration in neural tissues. Immunoreactivity specific to the glycan chains of keratan sulfate, heparan sulfate, and chondroitin sulfate in the olfactory region of the chick was found with antibodies and glycosidases. Localized distribution was seen in the olfactory epithelium, olfactory nerve and cells located along the bundles of the olfactory nerve. Chondroitin sulfate was found to be present in proteoglycan form in olfactory structures. Findings indicate the presence of heparan sulfate and chondroitin sulfate in migrating cells, whereas involvement of keratan sulfate in the migration of cells was ruled out [Nishizuka and Arai, 1996].

\section{Carbohydrate Differentiation Antigens in the Olfactory System}

Several different glycoconjugates are expressed in developing organs including the developing olfactory system. One of them is CDA-3C2, a carbohydrate differentiation antigen [Prouty and Levitt, 1993]. Carbohydrate differentiation antigens are known to display specific patterns of expression during mammalian development and are thought to participate in significant morphogenetic events. During neurulation of rats, antibodies to $\mathrm{CDA}-3 \mathrm{C} 2$ showed differential staining in the ectoderm, distinguishing lateral from neural regions. Following closure of the neural tube, there was a striking specificity of CDA-3C2 found almost exclusively in olfactory (and otic) epithelial structures. It appeared to be primarily associated with the supportive cells and their secretions and less with the sensory cells. This staining disappeared and was followed by appearance of rare receptor staining which itself was gone 2 weeks after birth. Although the postnatal and adult peripheral olfactory system were devoid of labeling, the olfactory bulb retained expression. This suggests that a unique carbohydrate antigen on a large macromolecule may be involved in neurulation and morphogenesis of the placode-derived olfactory structures, illustrating the complex genus-specific regulation of carbohydrate stuctures [Feizi and Childs, 1987].

\section{The Synaptic Vesicle Glycoprotein in the}

Olfactory System

Synaptophysin is a synaptic vesicle glycoprotein that provides a marker for synaptic distribution in the brain. Synaptophysin-like immunoreactivity appears early in the postnatal period in the olfactory bulb as has been examined in the rat. Immunoreactivity is especially dense along the aspect of the perimeter facing the olfactory nerve layer. Glomerular distribution of synaptophysin is particularly sensitive to early olfactory experience. In individuals deprived of early olfactory experience expression of this molecule is significantly reduced [Johnson et al., 1996]. In the diagnostic procedure of olfactory neuroblastoma, an uncommon tumor of the upper nasal cavity, synaptophysin is used frequently as marker [Hirose et al., 1995].

\section{Glycoconjugates as Olfactory Receptor Molecules}

\section{Membrane and Transmembrane Glycoconjugates}

A group of glycoconjugates is exclusively restricted to the olfactory system. These olfactory-specific glycoconjugates may act as olfactory receptor molecules. Antibodies to them inhibit binding of odorants effectively [Fesenko et al., 1988]. Anholt et al. [1990] have used a library of monoclonal antibodies against chemosensory cilia of the olfactory epithelium in the frog. Specific membrane glycoproteins with high affinity for camphor and decanal were isolated from rat olfactory epithelium. The molecular mass of these glycopoteins was approximately $140 \mathrm{kDa}$. They consisted ot two subunits ( 88 and $55 \mathrm{kDa}$ ) and were capable of binding the odorants. Antibodies to these glycoproteins inhibited both the electroolfactogram and the binding of camphor and decanal in rat, mouse, guinea pig and hamster olfactory mucosa.

In the vertebrate system glycoconjugates have been found to be responsible for the binding of pheromones. For example the pheromone $5 \alpha$-androst-16-en-3-one is bound by a glycoprotein in the olfactory epithelium of pigs and rats [Kraevskaya et al., 1992]. In search of olfactory receptor molecules a comprehensive electrophoretic mapping of membrane proteins in the olfactory cilia of the frog olfactory epithelium showed that most major and minor specific polypeptides of the sensory cilia were glycosylated whereas nonsensory cilia were practically devoid of glycoproteins [Chen and Lancet, 1984]. The antibody 18.1 produced against isolated frog olfactory cilia was found to react against a specific transmembrane glycoprotein, gp95, of the sensory organelles. This unique glycoprotein has been suggested as candidate olfactory receptor protein [Chen et al., 1986]. Another 59-kDa glycoprotein possibly involved in odorant recognition and transduction was visualized by Anholt et al. [1990] with the monoclonal antibody 8 in the frog. This glycoconjugate was found to exist as mem- 
brane-associated oligomer connected via intermolecular disulfide bridges and tagged with distinct N-linked highmannose-type glycan chains.

A transmembrane glycoprotein specific for the bovine olfactory system has been characterized by Lazard et al. [1990]. This 56-kDa glycoprotein is highly homologous to uridine 5'-diphosphate-glucuronosyl transferase and is enriched in the microsomal fraction of the epithelium. It is supposed that gp56 is involved in odorant modification or clearance from the olfactory tissue.

Glycoconjugates seem to be involved in the transduction of the olfactory message. The mammalian olfactory system may transduce odorant information via a G-proteinmediated adenosine-3', $5^{\prime}$-monophosphatase cascade whose functionality is further explained by Villalobo and Gabius [1998] in this issue. The gene for an adenylyl cyclase, which is expressed as glycosylated protein, has been cloned and its expression was localized in the sensory cilia of olfactory neurons [Bakalyar and Reed, 1990; Menco et al., 1992].

\section{Secreted Glycoproteins}

The olfactory neuroepithelium is lined with a layer of mucus which odorants must partition into and traverse in order to reach the chemosensory membrane of the receptor neurons. The composition of the mucus may influence access of odorants to the chemosensory membrane and affect the threshold for odorant recognition. Glycoproteins have been identified in several species as prominent components of the mucus. These proteins are members of a family of carrier proteins and they are secreted by the Bowman's glands or the nasal glands [Gladysheva et al., 1986].

In the frog olfactory neuroepithelium the $57-\mathrm{kDa}$ glycoprotein olfactomedin has been found to be the major glycoprotein of the mucus. Olfactomedin is recognized by several monoclonal antibodies and its carbohydrate part dominates its immunogenicity. Mature forms as well as nonglycosylated and partially glycosylated precursors of olfactomedin were identified [Bal and Anholt, 1993]. Olfactomedin undergoes posttranslational modifications including dimerization via intermolecular disulfide bridges and attachment of complex carbohydrate chains that contain $\mathrm{N}$-acetylglucosamine and terminal $\beta$ - $D$-galactoside sugars [Snyder et al., 1991]. Olfactomedin may be involved in the facilitation or interaction between odorants and olfactory receptors at the olfactory membranes. Moreover, its abundance and location suggest a structural role in mucus organization. It may be responsible for the primary architecture of this extracellular matrix by forming poly- mers via intermolecular disulfide bonds, which are covered with evenly spaced carbohydrate groups [Menco and Farbman, 1992; Yokoe and Anholt, 1993]. In the rat brain four structurally related, distinct neuron-specific glycoproteins similar to olfactomedin, have been isolated. The similarity between olfactomedin and these glycoproteins suggests that they share functional properties [Danielson et al., 1994].

A glycoprotein possibly acting as pheromone and odorant carrier is vomeromodulin, a $70-\mathrm{kDa}$ glycoprotein that was identified in and cloned from the nasal mucosa of adult rats [Khew-Goodall et al., 1991]. It is synthesized selectively in the acinal cells of the maxillary sinus component of the lateral nasal glands and in the acinar cells of the vomeronasal glands and posterior glands of the nasal septum. By in situ hybridization and immunocytochemistry expression of this glycoprotein was also characterized in the developing rat nasal mucosa and it was shown that expression of vomeromodulin is developmentally and differentially regulated. Although the specific function of vomeromodulin is not known its localization and occurrence in nasal mucus supports a function as carrier for delivery of pheromones and odorants. In addition the embryonic expression suggests its involvement in olfactory perireceptor processes in utero [Krishna et al., 1994; Rama Krishna et al., 1995].

\section{Conclusion}

This article offers an insight into the multiple roles of glycoconjugates in the olfactory system. They are involved in olfaction and thus are central to the function of this organ system. Moreover they play a role during development of the olfactory system by mediating cellular recognition, adhesion and migration, and this already during the earliest stages of placode morphogenesis. Finally, they seem to be important in olfactory regeneration, predominantly in axonal guidance and fasciculation. This latter role of glycoconjugates in the olfactory system is particularly interesting and needs to be elucidated further, as similarly discussed for the changes in glycoprotein glycosylation in disease by Brockhausen et al. [1998] in this issue. Learning more about this aspect may hold an answer to the unsolved problem of neuronal regeneration and even may allow to develop replacement strategies after neuronal loss. In summary, research in this field underscores that after a colorful past, reviewed by Sharon [1998] in this issue, research on glycans promises to be an exciting endeavor. 


\section{Acknowledgements}

The authors would like to thank Barbara Ruppel for professional drawings. Also, the excellent bibliographical assistance of Fatemeh Nemati is acknowledged.

\section{References}

Allen, W.K., R. Akeson (1985) Identification of a cell surface glycoprotein family of olfactory receptor neurons with a monoclonal antibody. J Neurosci 5: 284-296.

Anholt, R.R., A.E. Petro, A.M. Rivers (1990) Identification of a group of novel membrane proteins unique to chemosensory cilia of olfactory receptor cells. Biochemistry 29: 3366-3373

Bakalyar, H.A., R.R. Reed (1990) Identification of a specialized adenylyl cyclase that may mediate odorant detection. Science 250 : 1403-1406.

Baker, H., R.F. Spencer (1986) Transneuronal transport of peroxidase-conjugated wheat germ agglutinin from the olfactory epithelium to the brain of the adult rat. Exp Brain Res 63 . 461-473.

Bal, R.S., R.H. Anholt (1993) Formation of the extracellular mucous matrix of olfactory neuroepithelium: Identification of partially glycosylated and nonglycosylated precursors of olfactomedin. Biochemistry 32: 1047-1053.

Barber, P.C. (1989) Ulex europaeus agglutinin I binds exclusively to primary olfactory neurons in the rat nervous system. Neuroscience 30 : $1-9$.

Barber, P.C., G. Raisman (1978) Cell division in the vomeronasal organ of the adult mouse Brain Res 141: 57-66.

Breer, H. (1991) Molecular reaction cascades in olfactory signal transduction. J Steroid Biochem Mol Biol 39: 621-625.

Breer, H. (1996) Molecular basis of signal recognition in olfaction. Pflügers Arch 431(suppl 2). 311-312.

Breipohl, W. (1986) Ontogeny of Olfaction. Berlin, Springer.

Brinck, U., M. Korabiowska, R. Bosbach, H.-J. Gabius (1998) Detection of inflammation- and neoplasia-associated alterations in human large intestine by plant/invertebrate lectins, galectin-1 and neoglycoproteins. Acta Anat 161: 219-233.

Broadwell, R.D., B.J. Balin (1985) Endocytic and exocytic pathways of the neuronal secretory process and trans-synaptic transfer of wheat germ agglutinin-horseradish peroxidase in vivo. J Comp Neurol 242: 632-650.

Brockhausen, I., J. Schutzbach, W. Kuhns (1998) Glycoproteins and their relationship to human disease. Acta Anat 161: 36-78.

Caggiano, A.O., P.C. Brunjes (1993) Microglia and the developing olfactory bulb. Neuroscience 52: 717-724.
Calof, A.L., A.D. Lander (1991) Relationship between neuronal migration and cell-substratum adhesion: Laminin and merosin promote olfactory neuronal migration but are anti-adhesive. J Cell Biol 115: 779-794.

Chen, Z., D. Lancet (1984) Membrane proteins unique to vertebrate olfactory cilia: Candidates for sensory receptor molecules. Proc Natl Acad Sci USA 81: 1859-1863.

Chen, Z., D. Ophir, D. Lancet (1986) Monoclonal antibodies to ciliary glycoproteins of frog olfactory neurons. Brain Res 368: 329-338.

Cole, G.J., J.S. Elam (1983) Characterization of axonally transported glycoproteins in regenerating garfish olfactory nerve. J Neurochem 41 : 691-702.

Collins, G.G., L. Surtees (1986) 'Desensitization' of excitatory amino acid responses in the rat olfactory cortex. Neuropharmacology 25: 231-240.

Connolly, D.J., K. Patel, E.A. Seleiro, D.G. Wilkinson, J. Cooke (1995) Cloning, sequencing, and expressional analysis of the chick homologue of follistatin. Dev Genet 17: 65-77.

Croucher, S.J., C. Tickle (1989) Characterization of epithelial domains in the nasal passages of chick embryos: Spatial and temporal mapping of a range of extracellular matrix and cell surface molecules during development of the nasal placode. Development 106: 493-509.

Danguy, A., C. Decaestecker, F. Genten, I. Salomon, R. Kiss (1998) Application of lectins and glycoconjugates in histology and pathology. Acta Anat 161: 206-218.

Danguy, A., F. Genten, H.-J. Gabius (1991) Histochemical evaluation of application of biotinylated neoglycoproteins for the detection of endogenous sugar receptors in fish skin. Eur J Basic Appl Histochem 35: 341-357.

Danielson, P.E., S. Forss-Petter, E.L.F. Battenberg, L. deLecea, F.E. Bloom (1994) Four structurally distinct neuron-specific olfactomedinrelated glycoproteins produced by differential promoter utilization and alternative mRNA splicing from a single gene. J Neurosci Res 38: 468-478.

Edwards, D.A., R.A. Mather, S.G. Shirley, G.H. Dodd (1987) Evidence for an olfactory receptor which responds to nicotine - Nicotine as an odorant. Experientia 43: 868-873.

Farbman, A.I. (1986) Prenatal development of mammalian olfactory receptor cells. Chem Senses 11: 3-18.
Farbman, A.I. (1988) Cellular interactions in the development of the vertebrate olfactory system; in Margolis FL, TV Getchell (eds): Molecular Neurobiology of the Olfactory System. New York, Plenum Publishing.

Farbman, A.I. (1992) Growth of olfactory epithelial tissue in vitro: Lectin staining of axons. Microsc Res Tech 23: 173-180.

Farbman, A.I. (1994) Developmental biology of olfactory sensory neurons. Semin Cell Biol 5: 3-10.

Farbman, A.I., J.A. Buchholz (1992) Growth of olfactory epithelial tissue in vitro: Lectin staining of axons. Microsc Res Tech 23: 173-180.

Feizi, T., R.A. Childs (1987) Carbohydrates as antigenic determinants of glycoproteins. Biochem J 245: 1-11.

Ferri, D., G.E. Liquori (1989) Lectin histochemistry of secretory cell glycoconjugates in the nasal mucosa of Podarcis sicula campestris De Betta (Reptilia, Lacertidae). Basic Appl Histochem 33: 197-207.

Fesenko, E.E., V.I. Novoselov, M.F. Bystrova (1988) Properties of odour-binding glycoproteins from rat olfactory epithelium. Biochim Biophys Acta 937: 369-378.

Foster, J.D., M.L. Getchell, T.V. Getchell (1991) Identification of sugar residues in secretory glycoconjugates of olfactory mucosae using lectin histochemistry. Anat Rec 229: 525-544.

Foster, J.D., M.L. Getchell, T.V. Getchell (1992) Ultrastructural localization of sialylated glycoconjugates in cells of the salamander olfactory mucosa using lectin cytochemistry. Cell Tissue Res 267: 113-124.

Franceschini, V., F. Ciani (1991) Lectin histochemical study of olfactory neurons in the eel. Cell Mol Biol 37: 61-71.

Franceschini, V., F. Ciani (1993a) Lectin binding to the olfactory system in a shark, Scyliorhinus canicula. Folia Histochem Cytobiol 31: 133-137.

Franceschini, V., F. Ciani (1993b) Lectin histochemistry of cell-surface glycoconjugates in the primary olfactory projections of the newt. Cell Mol Biol 39: 651-658.

Franceschini, V., P.P. Giorgi, F. Ciani (1992) Primary olfactory terminations in the forebrain of amphibia: A comparative study with soybean agglutinin. J Hirnforsch 33: 627-635.

Franceschini, V., M. Lazzari, F. Ciani (1996) Identification of surface glycoconjugates in the olfactory system of turtle. Brain Res 725: 81-87. 
Franceschini, V., M. Lazzari, R.P. Revoltella, F. Ciani (1994) Histochemical study by lectin binding of surface glycoconjugates in the developing olfactory system of the rat. Int J Dev Neurosci 12: 197-206.

Fujisawa, H., T. Kitsukawa, A. Kawakami, S. Takagi, M. Shimizu, T. Hirata (1997) Roles of a neuronal cell-surface molecule, neuropilin, in nerve fasciculation and guidance. Cell Tissue Res 290: 465-470.

Fuss, B., E.-S. Wintergerst, U. Bartsch, M. Schachner (1993) Molecular characterization and in situ mRNA localization of the neural recognition molecule J1-160/180: A modular structure similar to tenascin. J Cell Biol 120 : 1237-1249.

Gabius, H.-J. (1991) Detection and function of mammalian lectins - with emphasis on membrane lectins. Biochim Biophys Acta 1071: $1-18$.

Gabius, H.-J. (1997a) Animal lectins. Eur J Biochem 243: 543-576.

Gabius, H.-J. (1997b) Concepts of tumor lectinology. Cancer Invest 15: 454-464.

Gabius, H.-J., A. Bardosi (1991) Neoglycoproteins as tools in glycohistochemistry. Progr Histochem Cytochem 22: 1-66.

Gabius, H.-J., S. Gabius (eds) (1993) Lectins and Glycobiology. Berlin, Springer.

Gabius, H.-J., S. Gabius (eds) (1997) Glycosciences: Status and Perspectives. Weinheim, Chapman \& Hall.

Gabius, H.-J., S. Gabius, T.V. Zemlyanukhina, N.V. Bovin, U. Brinck, A. Danguy, S.S. Joshi, K. Kayser, J. Schottelius, F. Sinowatz, L.F Tietze, F. Vidal-Vanaclocha, J.-P. Zanetta (1993) Reverse lectin histochemistry: Design and application of glycoligands for detection of cell and tissue lectins. Histol Histopathol 8: 369-383.

Getchell, T.V., Z. Su, M.L. Getchell (1993) Mucous domains: Microchemical heterogeneity in the mucociliary complex of the olfactory epithelium. Ciba Found Symp 179: 27-40.

Gheri, G., S. Gheri-Bryk, G.C. Balboni (1991) Sugar residues of glycoconjugates in the olfactory epithelium of the human fetus: Histochemical study using peroxidase-conjugated lectins. Boll Soc Ital Biol Sper 67: 781-788.

Gheri, G., S. Gheri-Bryk, G.C. Balboni (1992) Identification of sugar resiudes in human fetal olfactory epithelium using lectin histochemistry. Acta Anat 145: 167-174.

Gladysheva, O., D. Kukushkina, G. Martynova (1986) Glycoprotein composition of olfactory mucus in vertebrates. Acta Histochem 78: 141-146.

Gong, Q., M.T. Shipley (1996) Expression of extracellular matrix molecules and cell surface molecules in the olfactory nerve pathway during early development. J Comp Neurol 366 : $1-14$.

Graziadei, P.P.C., G.A. Monti-Graziadei (1979) Neurogenesis and neuron regeneration in the olfactory system of mammals. I. Morphological aspects of differentiation and structural organization of the olfactory sensory neurons. J Neurocytol 8: 1-18.
Hahnlein, I., W. Hartig, G. Bicker (1996) Datura stramonium lectin staining of glial associated extracellular material in insect brains. J Comp Neurol 376: 175-187.

Hakomori, S. (1998) Cancer-associated glycosphingolipid antigens: Their structure, organization and function. Acta Anat 161: 79-90.

Hees, H., F. Sinowatz (1992) Histologie. Kurzlehrbuch der Zytologie und mikroskopischen Anatomie. Köln, Deutscher Ärzteverlag.

Heimer, I., L. Zaborszky, D.S. Zahm, G.F. Alheid (1987) The ventral striatopallidothalamic projection. I. The striatopallidal link originating in the striatal parts of the olfactory tubercle. J Comp Neurol 255: 571-591.

Hempstead, J.L., J.I. Morgan (1983) Fluorescent lectins as cell-specific markers for the rat olfactory epithelium. Chem Senses 8: 107-120.

Hirose, T., B.W. Scheithauer, M.B. Lopes, H.A. Gerber, H.J. Altermatt, S.G. Harner, S.R. Vandenberg (1995) Olfactory neuroblastoma: An immunohistochemical, ultrastructural, and flow cytometric study. Cancer 76: 4-19.

Hofmann, M.H., D.L. Meyer (1991) Functional subdivisions of the olfactory system correlate with lectin-binding properties in Xenopus. Brain Res 564: 344-347.

Htain, W.W., S.K. Leong, E.A. Ling (1994) A comparative Mac-1 immunocytochemical and lectin histochemical study of microglial cells in the normal and athymic mice. Glia 12: 44-51.

Ichikawa, M. (1988) Plasticity of intra-amygdaloid connections following the denervation of fibers from accessory olfactory bulb to medial amygdaloid nucleus in adult rat: Immunohistochemical study of anterogradely transported lectin (Phaseolus vulgaris leucoagglutinin). Brain Res 451: 248-254.

Ichikawa, M., T. Osada, P.P.C. Graziadei (1994a) Vicia villosa agglutinin inhibits the fasciculation of vomeronasal axons in fetal rat vomeronasal organ culture. Brain Res 668: 252-255.

Ichikawa, M., T. Osada, A. Ikai (1992) Bandeiraea simplicifolia lectin I and Vicia villosa agglutinin bind specifically to the vomeronasal axons in the accessory olfactory bulb of the rat. Neurosci Res 13: 73-79.

Ichikawa, M., S. Takami, T. Osada, P.P.C. Graziadei (1994b) Differential development of binding sites of two lectins in the vomeronasal axons of the rat accessory olfactory bulb. Brain Res Dev Brain Res 78: 1-9.

Jackson, L.M., J.D. Harder (1996) Vomeronasal organ removal blocks pheromonal induction of estrus in gray short-tailed opossums (Monodelphis domestica). Biol Reprod 54: 506-512.

Johnson, B.A., C.C. Woo, K. Ninomiya-Tsuboi, M. Leon (1996) Synaptophysin-like immunoreactivity in the rat olfactory bulb during postnatal development and after restricted early olfactory experience. Brain Res Dev Brain Res 29: 24-30.

Kalinoski, D.L., R.C. Bruch, J.G. Brand (1987) Differential interaction of lectins with chemosensory receptors. Brain Res 418: 34-40.
Kaltner, H., K.S. Lips, G. Reuter, S. Lippert, F. Sinowatz, H.-J. Gabius (1997) Quantitation and histochemical localization of galectin-1 and galectin-1-reactive glycoconjugates in fetal development of bovine organs. Histol Histopathol 12: 945-960.

Kaltner, H., B. Stierstorfer (1998) Animal lectins as cell adhesion molecules. Acta Anat 161: $162-179$.

Kannan, S., N. Nair (1997) Lectins and neoglycoproteins in histopathology; in Gabius H-J, S Gabius (eds): Glycosciences: Status and Perspectives. Weinheim, Chapman \& Hall, pp 563-583.

Kayser, K., H.-J. Gabius (1997) Graph theory and the entropy concept in histochemistry. Prog Histochem Cytochem 32/2: 1-106.

Key, B., R.A. Akeson (1990) Olfactory neurons express a unique glycosylated form of the neural cell adhesion molecule (N-CAM). J Cell Biol 110: 1729-1743

Key, B., R.A. Akeson (1991a) Delineation of olfactory pathways in the frog nervous system by unique glycoconjugates and N-CAM glycoforms. Neuron 6: 381-396.

Key, B., R.A. Akeson (1991b) Distinct subsets of sensory olfactory neurons in mouse: Possible role in the formation of the mosaic projection. J Comp Neurol 335: 355-368.

Key, B., R.A. Akeson (1993) Distinct subsets of sensory olfactory neurons in mouse: Possible role in the formation of the mosaic olfactory projection. J Comp Neurol 335: 355-368.

Key, B., P.P. Giorgi (1985) Soybean lectin binding to the olfactory system of Xenopus; in Kande ER, P Calissano, A Maggi (eds): Molecular Aspects of Neurobiology. New York, Springer.

Key, B., P.P. Giorgi (1986a) Soybean agglutinin binding to the olfactory systems of the rat and mouse. Neurosci Lett 69: 131-136.

Key, B., P.P. Giorgi (1986b) Selective binding of soybean agglutinin to the olfactory system of Xenopus. Neuroscience 18: 507-515.

Key, B., A.C. Puche (1997) Role of galectin-1 in the olfactory nervous system. Trends Glycosci Glycotechnol 9: 41-45.

Khew-Goodall, Y., M. Grillo, M.L. Getchell, W Danho, T.V. Getchell, F.L. Margolis (1991) Vomeromodulin, a putative pheromone transporter: Cloning, characterization, and cellular localization of a novel glycoprotein of lateral nasal gland. FASEB J 5: 2976-2982.

Kobayashi, H., A.M. Koppel, Y. Luo, J.A. Raper (1997) A role of collapsin-1 in olfactory and cranial sensory axon guidance. J Neurosci 17 : 8339-8352.

Kolodkin, A.I., D.V. Levengood, E.G. Rowe, Y.T. Tai, R.J. Giger, D.D. Ginty (1997) Neuropilin is a semaphorin III receptor. Cell 90: 753-762.

Koppe, G., G. Bruckner, K. Brauer, W. Hartig, V. Bigl (1997) Developmental patterns of proteoglycan-containing extracellular matrix in perineuronal nets and neuropil of the postnatal rat brain. Cell Tissue Res 288: 33-41.

Kott, J.N., L.E. Westrum, A.M. Bhatia (1991) Is Phaseolus vulgaris leucoagglutinin a useful marker for labelling neural grafts? J Neural Transplant Plast 2: 249-253. 
Kraevskaya, M.A., M.J. Higgins, D.B. Gower (1992) Binding of $5 \alpha$-androst-16-en-3-one to glycoproteins of porcine olfactory tissue. Biochem Soc Trans 20: 372S.

Krishna, N.S., M.L. Getchell, T.V. Getchell (1994) Expression of the putative pheromone and odorant transporter vomeromodulin mRNA and protein in nasal chemosensory mucosae. J Neurosci Res 39: 243-259.

Lallier, T.E., C.A. Whittaker, D.W. DeSimone (1996) Integrin $\alpha 6$ expression is required for early nervous system development in Xenopus laevis. Development 122: 2539-2554.

Lazard, D., N. Tal, M. Rubinstein, M. Khen, D. Lancet, K. Zupko (1990) Identification and biochemical analysis of a novel olfactoryspecific cytochrome P-450IIA and UDPglucuronosyl transferase. Biochemistry 29: 7433-7440

Lincoln, D., F. Sinowatz, W. Breipohl, H.-J. Gabius (1991) Endogene Lektine im olfaktorischen System der Maus. Verh Anat Ges 84: 459-460.

Litwack, E.D., C.S. Stipp, A. Kumbasar, A.D. Lander (1994) Neuronal expression of glypican, a cell-surface glycosylphosphatidylinositolanchored heparan sulfate proteoglycan in the adult rat nervous system. J Neurosci 14 3713-3724

Lundh, B., U. Brockstedt, K. Kristensson (1989) Lectin-binding pattern of neuroepithelial and respiratory epithelial cells in the mouse nasal cavity. Histochem J 21: 33-43.

Macconell, L.A., S. Barth, V.J. Roberts (1996) Distribution of follistatin messenger ribonucleic acid in the rat brain: Implications for a role in the regulation of central reproductive functions. Endocrinology 137: 2150-2158.

Mahanthappa, N.K., D.N.W. Cooper, S.H. Barondes, G.A. Schwarting (1994) Rat olfactory neurons can utilize the endogenous lectin, L-14, in a novel adhesion mechanism. Development 120: 1373-1384.

Masson, J., X. Langlois, L. Lanfumey, C. Gerard, Z. Aidouni, B. Giros, M. Hamon, S. el-Mestikawy (1995) Immunolabelling of the $\mathrm{Na}+$ $\mathrm{Cl}(-)$-dependent 'orphan' transporter Rxt1 in the rat central nervous system. J Neurosci Res 42: 423-432.

Masson, J., M. Pohl, Z. Aidouni, B. Giros, M. Hamon, S. el-Mestikawy (1996) The two orphan $\mathrm{Na}+/ \mathrm{Cl}(-)$-dependent transporters $\mathrm{Rxt} 1$ and V-7-3-2 have an overlapping expression pattern in the rat central nervous system. Receptors Channels 4: 227-242.

Menco, B.P. (1989) Olfactory and nasal respiratory epithelia, and foliate taste buds visualized with rapid-freeze freeze-substitution and Lowicry K11M embedding. Ultrastructural and initial cytochemical studies. Scanning Microsc 3: 257-272.

Menco, B.P. (1992) Lectins bind differentially to cilia and microvilli of major and minor cell populations in olfactory and nasal respiratory epithelia. Microsc Res Tech 23: 181-199.

Menco, B.P.M., R.C. Bruch, B. Dau, W. Danho (1992) Ultrastructural localization of olfactory transduction components: The $\mathrm{G}$ protein subunit $\mathrm{G}_{\text {olf } \alpha}$ and type III adenylyl cyclase. Neuron 8: 441-453.
Menco, B.P., A.I. Farbman (1992) Ultrastructural evidence for multiple mucous domains in frog olfactory epithelium. Cell Tissue Res 270: 47-56.

Mendoza, A.S., B. Borish-Chépiuz, V. Kiunél (1989) Lectin-binding properties of the neuroepithelium of the vomeronasal organ, olfactory epithelium proper and the septal organ of Masera in mice. Arkh Anat Gistol Embriol 97: 76-81.

Mendoza, A.S., W. Kühnel (1991) Lectin histochemistry on the olfactory region and the vomeronasal organ of rats and golden hamsters. Acta Histochem 91: 173-184.

Meyer, D.L., I.R. Fackler, A.G. Jadhao, B. D'Aniello, E. Kicliter (1997) Differential labelling of primary olfactory system subcomponents by SBA (lectin) and NADPH-histochemistry in the frog Pipa. Brain Res 762: 275-280.

Meyer, D.L., A.G. Jadhao, E. Kicliter (1996) Soybean agglutinin binding by primary olfactory and primary accessory olfactory projections in different frogs. Brain Res 722: 222-226.

Mimmack, M.L., H. Saito, G. Evans, M. Bresler, E.B. Keverne, P.C. Emson (1997) A novel splice variant of the cell adhesion molecule BIG-2 is expressed in the olfactory and vomeronasal neuroepithelia. Brain Res Mol Brain Res 47: 345-350.

Miragall, F., G. Kadmon, M. Husmann, M. Schachner (1988) Expression of cell adhesion molecules in the olfactory system of the adult mouse: Presence of the embryonic form of N-CAM. Dev Biol 129: 516-531.

Murakami, F., Y. Tada, K. Mori, S. Oka, H. Katsamura (1991) Ultrastructural localization of telencephalin, a telencephalon-specific membrane glycoprotein, in rabbit olfactory bulb. Neurosci Res 11: 141-145.

Nagao, M., N. Oka, H. Kamo, I. Akiguchi, J. Kimura (1993) Ulex europaeus I and Glycine $\max$ bind to the human olfactory bulb. Neurosci Lett 164: 221-224.

Nakagawa, F., B.A. Schulte, S.S. Spicer (1986) Selective cytochemical demonstration of glycoconjugate-containing terminal $\mathrm{N}$-acetylgalactosamine on some brain neurons. J Comp Neurol 243: 280-290.

Naruse, I., Y. Fukui, H. Keino, M. Taniguchi (1994) The arrest of luteinizing hormonereleasing hormone neuronal migration in the genetic arhinencephalic mouse embryo (Pdn/Pdn). Brain Res Dev Brain Res 81: 178-184.

Nishizuka, M., Y. Arai (1996) Glycosaminoglycans in the olfactory epithelium and nerve of chick embryos: An immunocytochemical study. Neurosci Res 24: 165-173.

Norgren, R.B., R. Brackenbury (1993) Cell adhesion molecules and the migration of $\mathrm{LHRH}$ neurons during development. Dev Biol 160: 377-387.

Oakley, B., D.R. Riddle (1992) Receptor cell regeneration and connectivity in olfaction and taste. Exp Neurol 115: 50-54.
Oka, S., K. Mori, Y. Watanabe (1990) Mammalian telencephalic neurons express a segment-specific membrane glycoprotein telencephalin. Neuroscience 35: 93-103.

Okabe, H., T. Okubo, Y. Ochi (1996) Expression of an epithelial membrane glycoprotein by neurons arising from the human olfactory plate through development. Neuroscience 72 : 579-584.

Ono K., M. Tomasiewicz, T. Magnuson, U. Rutishauser (1994) N-CAM mutation inhibits tangential neuronal migration and is phenocopied by enzymatical removal of polysialic acid. Neuron 13: 595-609.

Pastor, L.M., L. Grana, M.J. Frutos, R. Villaverde, D. Ramos (1991) Lectin histochemistry of the olfactory surface in two teleostean fishes. Acta Histochem 90: 173-180.

Pellier, V., L. Astic (1994) Histochemical and immunocytochemical study of the migration of neurons from the rat olfactory placode. Cell Tissue Res 275: 587-598.

Pellier, V., D. Saucier, A.B. Oestreicher, L. Astic (1996) Ultrastructural and cytochemical identification of apoptotic cell death accompanying development of the fetal rat olfactory nerve layer. Anat Embryol 194: 99-109.

Pestean, A., I. Krizbai, H. Böttcher, A. Parducz, F. Joo, J.R. Wolff (1995) Identification of the Ulex europaeus agglutinin I binding protein as a unique glycoform of the neural cell adhesion molecule in the olfactory sensory axons of adult rats. Neurosci Lett 195: 117-120.

Pfenninger, K.H., M.F. Maylie-Pfenninger, L.B Friedman, P. Simkowitz (1984) Lectin labelling of sprouting neurons. III. Type-specific glycoconjugates on growth cones of different origin. Dev Biol 106: 97-108.

Plendl, J., W. Schmahl (1988a) Dolichos biflorus agglutinin: A marker of the developing olfactory system in the NMRI-mouse strain. Anat Embryol 177: 459-464.

Plendl, J., W. Schmahl (1988b) Dolichos biflorus agglutinin distinguishes mature olfactory neurons and synapses in the mouse; in Freed D, TC Bog-Hansen (eds): Lectins - Biology, Biochemistry, Clinical Biochemistry. St Louis, Sigma, vol 6, pp 663-670.

Polak, E.H., S.G. Shirley, G.H. Dodd (1989) Concanavalin A reveals olfactory receptors which discriminate between alkane odorants on the basis of size. Biochem J 262: 475-478.

Prouty, S.M., P. Levitt (1993) Immunocytochemical analysis of a novel carbohydrate differentiation antigen (CDA-3C2) associated with olfactory and otic systems during embryogenesis in the rat. J Comp Neurol 332: 444-470.

Puche, A.C., B. Key (1995) Identification of cells expressing galectin-1, a galactose-binding receptor, in the rat olfactory system. J Comp Neurol 357: 513-523.

Raabe, E.H., K. Yoshida, G.A. Schwarting (1997) Differential laminin isoform expression in the developing rat olfactory system. Brain Res Dev Brain Res 101: 187-196. 
Rama Krishna, N.S., M.L. Getchell, F.L. Margolis, T.V. Getchell (1995) Differential expression of vomeromodulin and odorant-binding protein, putative pheromone and odorant transporters, in the developing rat nasal chemosensory mucosae. J Neurosci Res 40: 54-71.

Riddle, D.R., L.D. Wong, B. Oakley (1993) Lectin identification of olfactory receptor neuron subclasses with segregated central projections. J Neurosci 13: 3018-3033.

Rüdiger, H. (1998) Plant lectins - More than just tools for glycoscientists. Occurrence, structure and possible functions of plant lectins. Acta Anat 161: 130-152.

Sadikot, A.F., A. Parent, C. François (1990) The centre median and parafascicular thalamic nuclei project respectively to the sensorimotor and associative-limbic striatal territories in the squirrel monkey. Brain Res 510: 161-165.

Sadikot, A.F., A. Parent, C. François (1992) Efferent connections of the centromedian and parafascicular thalamic nuclei in the squirrel monkey: A PHA-L study of subcortical projections. J Comp Neurol 315: 137-159.

Saito, H., K. Ogawa, K. Tanaguchi (1994) Lectinbinding pattern of vomeronasal respiratory epithelium in the rat. Jikken Dobutsu 43: 209-216.

Salazar, I., P.C. Barber, J.M. Cifuentes (1992) Anatomical and immunohistological demonstration of the primary neural connections of the vomeronasal organ in the dog. Anat Rec 233: $309-313$

Salazar, I., P.S. Quinteiro, J.M. Cifuentes, M. Lombardero (1998) The accessory olfactory bulb of the mink, Mustela vison: A morphological and lectin histochemical study. Anat Histol Embryol, in press

Satoda, M., S. Takagi, K. Ohta, T. Hirata, H. Fujisawa (1995) Differential expression of two cell surface proteins, neuropilin and plexin, in Xenopus olfactory axon subclasses. J Neurosci 15: 942-955.

Schoenfeld, T.A., J.E. Marchand, F. Macrides (1985) Topographic organization of tufted cell axonal projections in the hamster main olfactory bulb: An intrabulbar associational system. J Comp Neurol 235: 503-518.

Schwaighofer-Breuer, M. (1992) Histologische und histochemische Untersuchungen am Riechepithel der Fledermäuse Carollia perspicillata und Rhinolophus rouxi; Diss. med. vet., University of Munich.

Schwarting, G.A., J.E. Crandall (1991) Subsets of olfactory and vomeronasal sensory epithelial cells and axons revealed by monoclonal antibodies to carbohydrate antigens. Brain Res 547: 239-248.

Schwarting, G.A., G. Deutsch, D.M. Gattey, J.E. Crandall (1992) Glycoconjugates are stageand position-specific cell surface molecules in the developing olfactory system. 1 . The $\mathrm{CC} 1$ immunoreactive glycolipid defines a rostrocaudal gradient in the rat vomeronasal system. J Neurobiol 23: 120-129.
Schwarting, G.A., D. Drinkwater, J.E. Crandall (1994) A unique neuronal glycolipid defines rostrocaudal compartmentalization in the accessory olfactory system of rats. Dev Brain Res 78: 191-200.

Schwob, J.E., J.M. Huard, M.B. Luskin, S.L. Youngentob (1994) Retroviral lineage studies of the rat olfactory epithelium. Chem Senses 19: 671-682.

Scott, J.W., J. Pemberton (1984) Mitral and tufted cells of the rat olfactory bulb visualized by injection of the Phaseolus vulgaris leucoagglutinin. Neurosci Abstr 10: 859

Shapiro, L.S., M. Halpern (1995) Lectin histochemical identification of carbohydrate moieties in opossum chemosensory systems during development with special emphasis on VVAidentified subdivisons in the accessory olfactory bulb. J Morphol 224: 331-349.

Shapiro, L.S., R.M. Roland, C.S. Li, M. Halpern (1996) Vomeronasal system involvement in response to conspecific odors in adult male opossums, Monodelphis domestica. Behav Brain Res 77: 101-113.

Sharon, N. (1998) Glycoproteins now and then. Acta Anat 161: 7-17.

Shepherd, I., Y. Luo, J.A. Raper, S. Chang (1996) The distribution of collapsin-1 mRNA in the developing chick nervous system. Dev Biol 173: 185-199.

Shipley, M.T. (1985) Transport of molecules from nose to brain: Transneuronal anterograde and retrograde labelling in the rat olfactory system by wheat germ agglutinin-horseradish peroxidase applied to the nasal epithelium. Brain Res Bull 15: 129-142.

Shnayder-Shapiro, L., P.-L. Ee, M. Halpern (1995) Lectin histochemical identification of carbohydrate moieties in opossum chemosensory systems during development, with special emphasis on VVA-identified subdivisions in the accessory olfactory bulb. J Morphol 224: 331-349

Silverman, J.D., L. Kruger (1990) Selective neuronal glycoconjugate expression in sensory and autonomic ganglia: Relation of lectin reactivity to peptide and enzyme markers. J Neurocytol 19: 789-801.

Simonneau, L., F. Broders, J.P. Thiery (1992) NCadherin transcripts in Xenopus laevis from early tailbud to tadpole. Dev Dyn 194: 247-260.

Smuts, M.S. (1977) Concanavalin A binding to the epithelial surface of the developing mouse olfactory placode. Anat Rec 188: 29-37.

Snyder, D.A., A.M. Rivers, H. Yokoe, B.P. Menco, R.R. Anholt (1991) Olfactomedin: Purification, characterization, and localization of a novel olfactory glycoprotein. Biochemistry 30: 9143-9153.

Stallcup, W.B., L.L. Beasley, J.M. Levine (1985) Antibody against nerve growth factor-inducible large external (NILE) glycoprotein labels nerve fiber tracts in the developing rat nervous system. J Neurosci 5: 1090-1101.

Stewart, W.B., C.E. Touloukian (1996) Lotus lectin labels subpopulation of olfactory receptor cells. Chem Senses 21: 13-18.
Struyk, A.F., P.D. Canoll, M.J. Wolfgang, C.L. Rosen, P. D'Eustachio, J.L. Salzer (1995) Cloning of neurotrimin defines a new subfamily of differentially expressed neural cell adhesion molecules. J Neurosci 15: 2141-2156.

Sugimoto, K., S. Honda, T. Yamamoto, T. Ueki, M. Monden, A. Kaji, K. Matsumoto, T. Nakamura (1996) Molecular cloning and characterization of a newly identified member of the cadherin family, PB-cadherin J Biol Chem 271: 11548-11556

Suzuki, Y., N. Sato, M. Tohyama, A. Wanaka, T. Takagi (1996) cDNA cloning of a novel membrane glycoprotein that is expressed specifically in glial cells in the mouse brain, LIG-1, a protein with leucine-rich repeats and immunoglobulin-like domains. J Biol Chem 271: 22522-22527.

Takami, S., M.L. Getchell, T.V. Getchell (1994) Lectin histochemical localization of galactose, $\mathrm{N}$-acetylgalactosamine, and $\mathrm{N}$-acetylglucosamine in glycoconjugates of the rat vomeronasal organ, with comparison to the olfactory and septal mucosae. Cell Tissue Res 277: 211-230.

Takami, S., M.L. Getchell, T.V. Getchell (1995) Resolution of sensory and mucoid glycoconjugates with terminal $\alpha$-galactose residues in the mucomicrovillar complex of the vomeronasal sensory epithelium by dual confocal laser scanning microscopy. Cell Tissue Res 280: 211-216.

Takami, S., P.P. Graziadei, M. Ichikawa (1992) The differential staining pattern of two lectins in the accessory olfactory bulb of the rat. Brain Res 598: 337-342.

Takami, S., K. Hirosawa (1987) Light microscopic observations of the vomeronasal organ of Habu, Trimeresurus flavoviridis. Jpn J Exp Med 57: 163-174.

Taniguchi, K., Y. Nii, K. Ogawa (1993) Subdivisions of the accessory olfactory bulb, as demonstrated by lectin-histochemistry in the golden hamster. Neurosci Lett 158: 185-188.

Tobet, S.A., T.W. Chickering, S.A. Sower (1996) Relationship of gonadotropin-releasing hormone (GnRH) neurons to the olfactory system in developing lamprey (Petromyzon marinus). J Comp Neurol 376: 97-111.

Tobet, S.A., J.E. Crandall, G.A. Schwarting (1993) Relationship of migrating luteinizing hormone-releasing hormone neurons to unique olfactory system glycoconjugates in embryonic rats. Dev Biol 155: 471-482.

Treloar, H., H. Tomasiewicz, T. Magnuson, B. Key (1997) The central pathway of primary olfactory axons is abnormal in mice lacking the N-CAM-180 isoform. J Neurobiol 32: 643-658.

Treloar, H., E. Walter, F. Margolis, B. Key (1996) Olfactory glomeruli are innervated by more that one distinct subset of primary sensory olfactory neurons in mice. J Comp Neurol 367 : $550-562$.

Ueno, K., Y. Hanamure, M. Ohyama (1994) Differences in terminal carbohydrate structures of sialomucin in the murine nasal cavity. Eur Arch Otorhinolaryngol 251: 119-122. 
Villalobo, A., H.-J. Gabius (1998) Signaling pathways for transduction of the initial message of the glycocode into cellular responses. Acta Anat 161: 110-129.

von der Lieth, C.-W., H.-C. Siebert, T. Kozár, M. Burchert, M. Frank, M. Gilleron, H. Kaltner, G. Kayser, E. Tajkhorshid, N.V. Bovin, J.F.G. Vliegenthart, H.-J. Gabius (1998) Lectin ligands: New insights into their conformations and their dynamic behavior and the discovery of conformer selection by lectins. Acta Anat 161: $91-109$.

Wallis, I., L. Ellis, K. Suh, K.H. Pfenninger (1985) Immunolocalization of a neuronal growth-dependent membrane glycoprotein. J Cell Biol 101: 1990-1998.

Watanabe, E., F. Matsui, H. Keino, K. Ono, Y. Kushima, M. Noda, A. Oohira (1996) A membrane-bound heparan sulfate proteoglycan that is transiently expressed on growing axons in the rat brain. J Neurosci Res 44: 84-96.

Whitesides, J.G. III, A.-S. LaMantia (1995) Distinct adhesive behaviors of neurons and neural precursor cells during regional differentiation in the mammalian forebrain. Dev Biol 169 . 229-241.

Whitesides, J.G. III, A.-S. LaMantia (1996) Differential adhesion and the initial assembly of the mammalian olfactory nerve. J Comp Neurol 373: $240-254$.
Woolf, N.J., M.C. Hernit, L.L Butcher (1986) Cholinergic and non-cholinergic projections from the rat basal forebrain revealed by combined choline acetyltransferase and Phaseolus vulgaris leucoagglutinin immunohistochemistry. Neurosci Lett 66: 281-286.

Wray, S., S. Key, R. Qualle, S.M. Fusheko (1994) A subset of peripherin positive olfactory axons delineates the luteinizing hormone-releasing hormone neuronal migratory pathway in developing mouse. Dev Biol 166: 349-354.

Wu, C.H., H.F. Chien, C.Y. Chang, E.A. Ling (1997) Heterogeneity of antigen expression and lectin labelling on microglial cells in the olfactory bulb of adult rats. Neurosci Res 28: 67-75.

Wysocki, C.J., J.J. Lepri (1991) Consequences of removing the vomeronasal organ. J Steroid Biochem Mol Biol 39: 661-669.

Xue, G.P, R.A. Calvert, R.J. Morris (1990) Expression of the neuronal surface glycoprotein Thy-1 is under posttranscriptional control, and is spatially regulated, in the developing olfactory system. Development 109: 851-864.

Yokoe, H., R.R. Anholt (1993) Molecular cloning of olfactomedin, an extracellular matrix protein specific to olfactory neuroepithelium. Proc Natl Acad Sci USA 90: 4655-4659.
Yoshida, K., S.A. Tobet, J.E. Crandall, T.P. Jimenez, G.A. Schwarting (1995) The migration of luteinizing hormone-releasing hormone neurons in the developing rat is associated with a transient, caudal projection of the vomeronasal nerve. J Neurosci 15: 7769-7777.

Yoshihara, Y., M. Kawasaki, A. Tamada, H. Fujita, H. Hayashi, H. Kagamiyama, K. Mori (1997) OCAM: A new member of the neural cell adhesion molecule family related to zone-tozone projection of olfactory and vomeronasal axons. J Neurosci 17: 5830-5842.

Zahm, D.S., L. Heimer (1985) Synaptic contacts of ventral striatal cells in the olfactory tubercle of the rat: Correlated light and electron microscopy of anterogradely transported Phaseolus vulgaris-leucoagglutinin. Neurosci Lett 60: 169-175.

Zanetta, J.-P. (1998) Structure and functions of lectins in the central and peripheral nervous system. Acta Anat 161: 180-195.

Zschäbitz, A. (1998) Glycoconjugate expression and cartilage development in the cranial development. Acta Anat 161: 254-274. 